\title{
Baseline Assessments and Analysis of Fish, Macroinvertebrates and Herpetofauna in the Otter Creek Coal Tracts Area of Powder River County
}

\author{
Prepared for:
}

Pat Farmer, Project Manager/Director

Westech Environmental Services

Helena Field Office

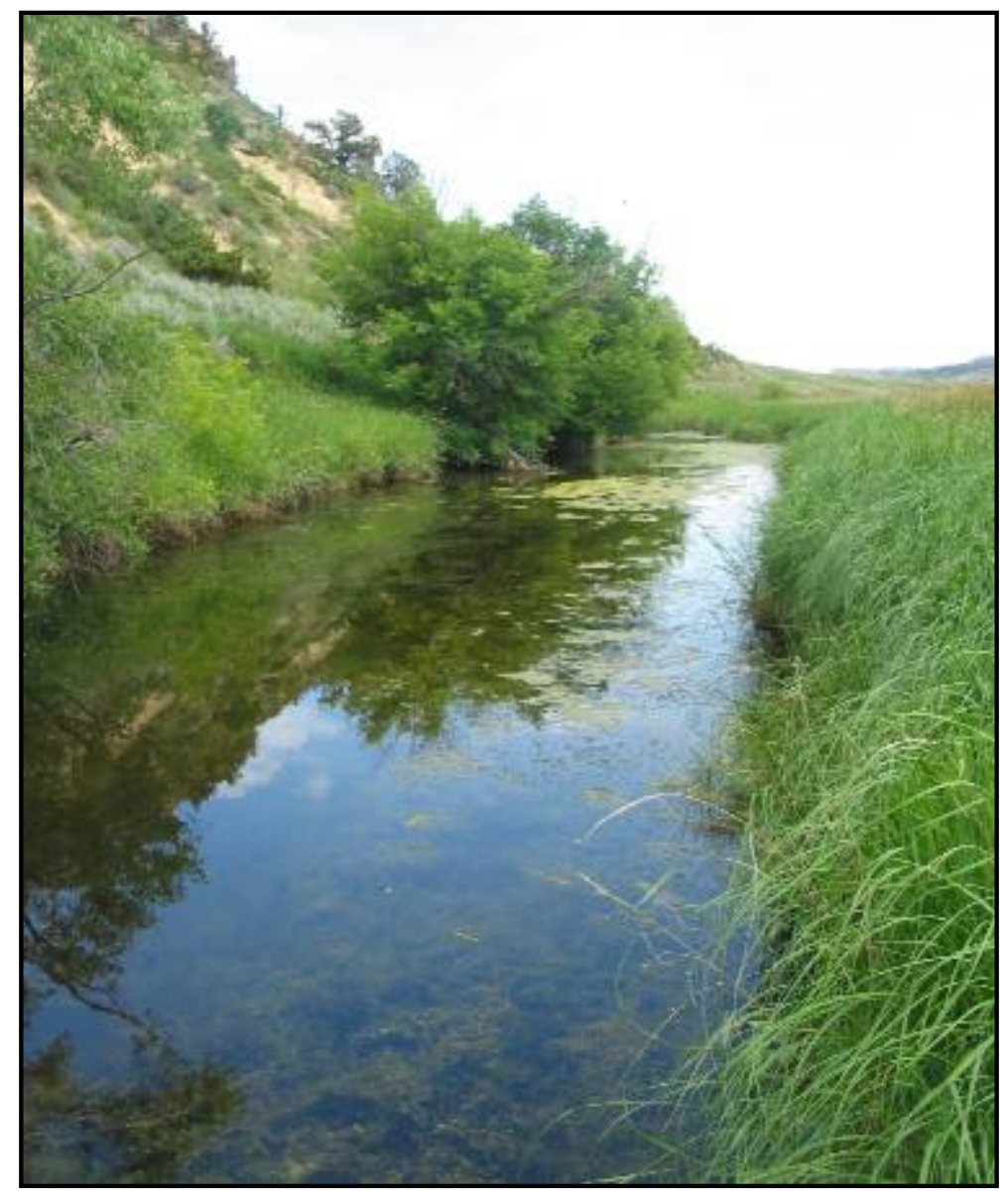

Prepared by:

David Stagliano, Aquatic Ecologist

Montana Natural Heritage Program

a cooperative program of the

Montana State Library and the University of Montana

January 2012

MONTANA

Natural Heritage

Program 


\section{Executive Summary}

We summarize the first year of baseline surveys for the Aquatic Assessment of Fish, Macroinvertebrates, and Herpetofauna in the Otter Creek coal tracts area. Project goals were: 1 ) to conduct standardized surveys and collect baseline information on the aquatic and riparian communities occurring in Otter Creek and three tributaries (seasonally and spatially oriented) prior to coal development, 2 ) to assess aquatic community integrity and condition by interpreting key indicators recorded at sites using standardized protocols and biotic thresholds, and to compare these against reference condition standards. These data collected represent predevelopment (i.e. pre-impact, $\mathrm{BACl}$ design) conditions at the local reach scale.

Habitat assessments, herpetofauna, macroinvertebrate and fish surveys were performed seasonally at three predetermined mainstem Otter Creek reaches (control, impact and downstream) and three tributaries coinciding with established surface water quality stations during 2011. Additionally, we added fish sampling visits to Otter Creek Impact \#2 (upstream of the Threemile Creek confluence) because Threemile Creek remained "dry" during all visits. In total, we performed 15 surveys for fish during the visits: 11 at four mainstem Otter Creek reaches and four surveys at two tributary streams. Fifteen macroinvertebrate samples were collected during the visits; neither taxa survey was conducted at Threemile Creek in any season due to lack of surface water present. All six a priori stream reaches were visually surveyed for amphibians or reptiles during all visits. Biological community integrity was calculated for 15 fish surveys using Fish Integrated Biotic Indices (IBI's) and Observed/Expected Models (O/E), while the 15 macroinvertebrate samples were assessed with Montana DEQ's multi-metric indices (MT MMI).

Habitat Evaluations. Of the seven sampling reaches evaluated in the study area, we found three in Proper Functioning Condition (PFC) with a stable trend and four were Functional at Risk (FAR). Reasons that sites ranked FAR were likely due to anthropogenic habitat alteration by cattle (Home Creek \{Otter_1A\} and Threemile Creek \{Otter_3m\}) or stream manipulation (Otter Creek JTTrussler and Otter Creek \#16). Highest site integrity scores using both the BLM Habitat and PFC Assessment methods were recorded at the Otter Creek sites \#23 (Tenmile Creek) and \#22 (controlDenson reach). Sites with lower habitat scores were structurally degraded predominately by cattle use and had high associated Livestock Use Indices (LUI) (Home Creek, Threemile and Otter Creek \#16-fall). Point conductivity measurements recorded at all Otter Creek mainstem sites across most seasons were above the threshold for impairment levels (>500 $\mu$, DEQ 2006), and Home Creek site $1 \mathrm{~A}$ had visible signs of natural gas seepage from the sediments.

Macroinvertebrate Communities: Overall, 104 unique macroinvertebrate taxa were reported from the 15 macroinvertebrate assessment samples. One known Montana species of concern (SOC), the mayfly, Caenis youngi was collected in fair numbers at the control site, Otter Creek \#22. Average macroinvertebrate taxa richness per site was 29.5 and the highest taxa richness was 41 taxa reported at the Otter Creek JT site. Using the Montana DEQ macroinvertebrate multimetric index (MMI), four of the five sites (12 of 15 samples) were ranked non-impaired (good to excellent biological integrity), while all three samples from Tenmile Creek were ranked marginally impaired. Stream sites that maintained flowing, connected water scored higher with the MMI than sites with 
interrupted pool areas. Overall, mainstem sites evaluated in the Otter Creek study received significantly higher macroinvertebrate MMI scores than those in the tributaries (T-test, $p<0.01$ ). MMI's did not significantly differ on Otter Creek mainstem Pre-Impact Control, Impact or Downstream Sites (T-test, $p>0.05$ ), despite the fish communities reflecting a decrease in biotic integrity.

Fish Communities. Overall, nine fish species (five native/four introduced) were identified from 37,679 individuals collected from 15 site visits (Table 4). One potential species of concern (PSOC), the brassy minnow, was collected at five of six sites. Average fish species per Otter Creek mainstem site across all seasons was 6.5 ( $\pm 0.8 \mathrm{SE}$ ), while the tributary sites averaged 1.75 species (Table 4). All fish presence sites also reported at least one species of amphibian. Lake chubs had the highest site occupancy rate at $93 \%$ (14 of 15 visits) followed by fathead and brassy minnows at $80 \%$ (12 of 15 visits). Fish data collected in previous years from three sites within the study area showed similar biological integrity over time. The most diverse site in the study area was Otter Creek JT site with nine species, while the most intact sites were Otter Creek Site \#22 at Denson's (four native) and the Tenmile Creek spring survey (two native spp.). Using Montana's Prairie Fish $\mid \mathrm{BI}, 9$ of the 15 fish sites were ranked non-impaired (good biological integrity), two were slightly impaired (moderate integrity) and four were moderately impaired (poor biotic integrity). Fish IBI's decreased going downstream on Otter Creek, and the Pre-Impact Control Site scored significantly higher than Impact or Downstream sites (T-test, $p<0.05)$.

Amphibian and Reptile Incidentals. Eight herpetofauna species were observed, collected in dipnets/seines or incidentally recorded in conjunction with the fish, habitat and macroinvertebrate surveys. We reported four amphibian species, of which, Woodhouse's Toad (Bufo woodhousii) had the highest site occupancy, occurring at six of seven sites, followed by the Northern Leopard Frog (Rana pipiens) and Tiger Salamander (Ambystoma tigrinum) recorded at five and four sites, respectively. Boreal Chorus Frog (Pseudacris maculata) was detected at three sites during the spring visits only. We also recorded four reptile species (in order of site occurrence): Western Rattlesnake (Crotalus viridis), Painted Turtle (Chrysemys picta), Terrestrial Garter Snake, (Thamnophis elegans) and Snapping Turtle (Chelydra serpentine) (SOC).

Conclusions. The aquatic community sampling sites chosen for pre-impact baseline data were representative of the range of stream classes found in the Otter Coal Tracts project area: Ephemeral, Intermittent and Perennial Prairie Streams. Despite this having been an unusually high water year for the region, stream communities that we sampled encompassed the range of expected species to occur in these stream types. Biotic integrity of sites was initially higher in the upstream control reaches of Otter Creek. One extraordinary finding was the high density and large biomass of fish inhabiting the stream reach below Trusler's Ranch road crossing ( 20,000 fish in the $300 \mathrm{~m}$ reach fall survey, $15 \mathrm{fish} / \mathrm{m}^{2}$ ); this was most likely an artifact of the impassible culvert located here and the fish "stacking up" downstream of this barrier. Density dependent fish anomalies (lesions and parasites, i.e., yellow grub and anchorworm) were prevalent at this site, indicating the fish were likely experiencing stress from overcrowding. Benthic macroinvertebrate densities at this site were low, but, more diverse than other sites, indicating that the fish may have been consuming large portions of the available insect production, having a top-down community effect. 


\section{TABLE OF CONTENTS}

INTRODUCTION

METHODS

Study Area

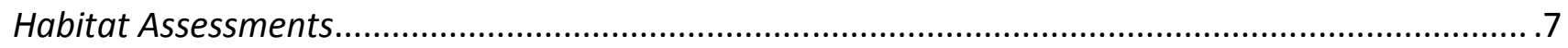

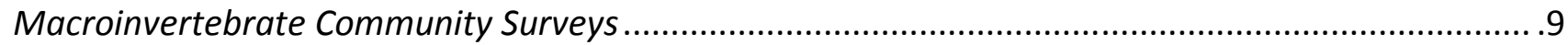

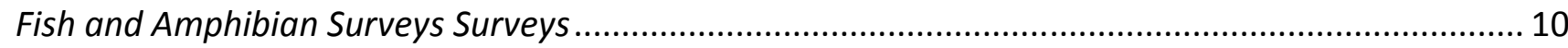

RESULTS

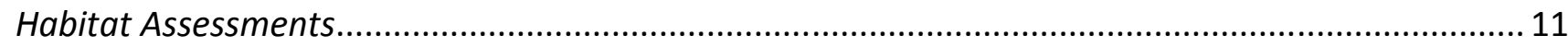

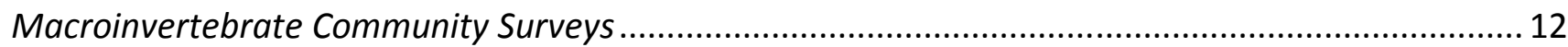

Fish Communities ................................................................................................................ 14

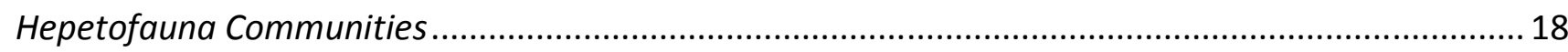

CONCLUSIONS

SITE PHOTOS

LITERATURE CITED

APPENDIX A. Fish data and IBI metric calculations collected from Otter Creek Project Sites

APPENDIX B. Macroinvertebate taxa list, abundance and metrics for the 15 collection sites

\section{List of Figures}

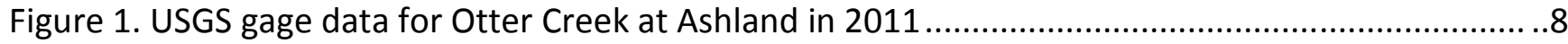

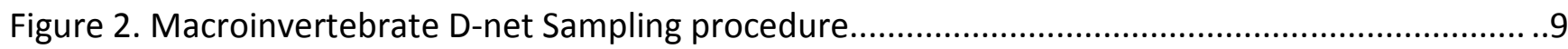

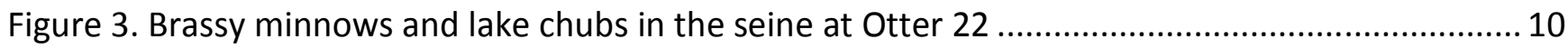

Figure 4. Photo of a structurally cattle-damaged, functional-at-risk (FAR) stream reach....................... 11

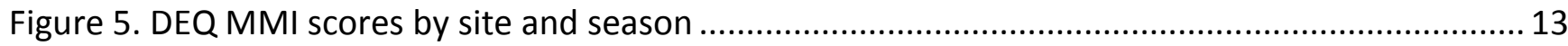

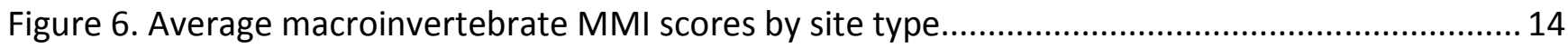

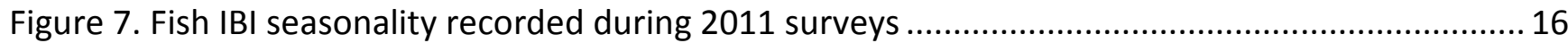

Figure 8. Comparison of the Fish IBI and O/E scores between sites and season ................................. 17

Figure 9. Average fish IBI scores by BACl design site type ............................................................... 17

\section{List of Tables}

Table 1. Otter Creek Study site GPS locations of reach ....................................................................

Table 2. Impairment determinations from the MMI and O/E (RIVPACS) models ..................................

Table 3. Fish metrics and classification of fish species captured in the study area................................ 11

Table 4. Macroinvertebrate sample characteristics and metrics used for the DEQ MMI ..................... 13

Table 5. Fish abundance, IBI and O/E scores for the 12 surveys reporting fish................................... 15

Table 6. Species of vertebrates collected during the aquatic surveys in 2011 .................................... 18

Table 7. Otter Creek Temporal Habitat Scores, Fish IBls and MMIs .................................................... 19 


\section{Acknowledgements}

We would like to thank Pat Farmer of Westech Environmental Services of Helena for funding this project under agreement \# L08AC13222. Report review and editing was provided by Stephen Fernandes and Linda Vance. Field work coordination, landowner contacts and logistics were greatly expediated by Carl Lenz and Heidi Kaiser (Hydrometrics, Inc.). Fieldwork assistance provided by Stephen Fernandes (MTNHP) was invaluable.

All photos in the report were taken by MTNHP personnel, unless otherwise noted 


\section{Introduction}

The Otter Creek basin in southeast Montana is currently undergoing exploration for a large, openpit coal mine. Baseline data on the condition of the ecosystem prior to coal mine development (pre-impact) is essential to determine what effects the coal extraction might have on the fish and wildlife in, and downstream of, the effected extraction area (post-impact). The initial mining rights transfer determined that no Federally Listed species under the ESA would be affected in the coal tracts area (BLM EA 2002). But this EA did not take into account the presence of Montana species of concern (SOC) or other ecologically sensitive native species assemblages. Despite numerous projects undertaken to document and monitor biological communities in the Powder and Tongue River watersheds in the wake of CBNG development (Confluence Consulting Inc. 2003, 2004; Stagliano 2006; Davis et al. 2009; Maxell 2009; Petersen et al. 2009; Senecal 2009, Stagliano 2011), large gaps still exist in basic baseline surveys for riparian macroinvertebrate, fish, and herpetofauna in the Otter Creek basin. Fish communities have been documented to be seasonally variable in prairie streams (Bramblett and Fausch 1991), thus sampling across all seasons is a good strategy to document baseline community differences. Many of the remaining data gaps involve small prairie streams that constitute the Northwestern Great Plains Intermittent Prairie Stream ecological system (Stagliano 2005). This stream system may have downstream connectivity early in the season for potential fish spawning and nursery areas (Smith and Hubert 1989, Bramblett 2000) or no fish colonization at all, but by summer often becomes a string of isolated pools that are important breeding and rearing areas for amphibians (Stagliano 2011). Identifying baseline communities and conditions in streams of the coal tracts area (i.e., the presence of fish, macroinvertebrate, and herpetofauna) prior to coal development is essential to understanding and potentially mitigating impacts to habitats and species during and after coal extraction.

\section{Methods}

\section{Study Sites}

The aquatic community sampling sites chosen for pre-impact baseline data are representative of the range of streams found in the Otter Coal Tracts project area: Ephemeral, Intermittent and Perennial Prairie Streams. Three predetermined mainstem Otter Creek reaches (control, impact and downstream) and three tributaries coinciding with established surface water quality stations were visited seasonally (May, July, October) during 2011 (Table 1). Additionally, we added fish sampling visits to Otter Creek site \#2 near the Threemile Creek confluence, since Threemile Creek remained "dry" during all visits (see Site Photos). Study site visits were timed with season and discharge (Figure 1); although we tried to coordinate field visits with baseflow water levels, 2011 was an 
Table 1. Otter Creek Coal Study Site GPS Locations at the top (T) and bottom (B) of the assessment reach. Aquatic Ecological System (AES) code described in text followed Stagliano (2005).

\begin{tabular}{|c|c|c|c|c|c|c|c|}
\hline Site Code & Site Name & Type & AES code & Latitude & Longitude & $\begin{array}{l}\text { Elev } \\
\text { (m) }\end{array}$ & Comment \\
\hline $\begin{array}{l}\text { Otter_23 } \\
\text { Otter_23 }\end{array}$ & $\begin{array}{l}\text { Tenmile Creek ( } T \text { ) } \\
\text { Tenmile Creek (B) }\end{array}$ & Control & D005/E005 & $\begin{array}{r}45.43409 \\
45.43465\end{array}$ & $\begin{array}{l}-106.13403 \\
-106.13253\end{array}$ & $\begin{array}{l}961 \\
958\end{array}$ & $\begin{array}{c}\text { Spring survey for fish } \\
\text { above the road reach, } \\
\text { dry during July, Oct. } \\
\text { visits }\end{array}$ \\
\hline $\begin{array}{l}\text { Otter_22 } \\
\text { Otter_22 }\end{array}$ & $\begin{array}{l}\text { Otter Creek } 22 \text { (T) } \\
\text { Otter Creek } 22 \text { (B) }\end{array}$ & $\begin{array}{l}\text { Control } \\
\text { Control }\end{array}$ & $\begin{array}{l}\text { D005/C005 } \\
\text { D005/C005 }\end{array}$ & $\begin{array}{l}45.43035 \\
45.43274\end{array}$ & $\begin{array}{l}-106.14428 \\
-106.14366\end{array}$ & $\begin{array}{l}951 \\
948\end{array}$ & $\begin{array}{l}\text { Top of reach began } \\
\sim 60 \mathrm{~m} \text { below Tenmile } \\
\text { Creek road, } \\
\text { proceeded } 300 \mathrm{~m} \\
\text { downstream }\end{array}$ \\
\hline $\begin{array}{l}\text { Otter_16 } \\
\text { Otter } 16\end{array}$ & $\begin{array}{l}\text { Otter Creek } 16 \text { (T) } \\
\text { Otter Creek } 16 \text { (B) }\end{array}$ & $\begin{array}{l}\text { Impact } \\
\text { Impact }\end{array}$ & $\begin{array}{l}\mathrm{CO05} \\
\mathrm{CO05}\end{array}$ & $\begin{array}{l}45.48514 \\
45.48365\end{array}$ & $\begin{array}{l}-106.16487 \\
-106.16725\end{array}$ & $\begin{array}{l}938 \\
937\end{array}$ & $\begin{array}{l}\text { Top of reach began } \\
\sim 60 \mathrm{~m} \text { above the } \\
\text { stream crossing and } \\
\text { went } 240 \mathrm{~m} \text { below }\end{array}$ \\
\hline $\begin{array}{l}\text { Otter_3m } \\
\text { Otter_3m }\end{array}$ & $\begin{array}{l}\text { Threemile Creek (T) } \\
\text { Threemile Creek (B) }\end{array}$ & Impact & E005 & 45.50955 & $\begin{array}{r}-106.16288 \\
-106.16960 \\
\end{array}$ & 928 & $\begin{array}{c}\text { Spring survey } \\
\text { contained standing } \\
\text { water in cattle hoof } \\
\text { prints, dry during July, } \\
\text { Oct. visits } \\
\end{array}$ \\
\hline $\begin{array}{l}\text { Otter_2 } \\
\text { Otter_2 }\end{array}$ & $\begin{array}{l}\text { Otter Creek } 2 \text { (T) } \\
\text { Otter Creek } 2 \text { (B) }\end{array}$ & $\begin{array}{l}\text { Impact } \\
\text { Impact }\end{array}$ & $\begin{array}{l}\mathrm{CO05} \\
\mathrm{CO05} \\
\end{array}$ & $\begin{array}{r}45.50475 \\
45.50561 \\
\end{array}$ & $\begin{array}{l}-106.17493 \\
-106.17561 \\
\end{array}$ & 929 & $\begin{array}{l}\text { Site added for fish } \\
\text { surveys during July } \\
\text { visit (unseinable in } \\
\text { Spring), downstream } \\
\text { of road crossing }\end{array}$ \\
\hline $\begin{array}{l}\text { Otter_JT } \\
\text { Otter_JT }\end{array}$ & $\begin{array}{l}\text { Otter Creek JT (T) } \\
\text { Otter Creek JT (B) }\end{array}$ & $\begin{array}{l}\text { Down } \\
\text { Down }\end{array}$ & CO05 & 45.55675 & $\begin{array}{l}-106.21798 \\
-106.21770\end{array}$ & $\begin{array}{l}910 \\
909\end{array}$ & $\begin{array}{l}\text { Top of reach began } \\
\sim 80 \mathrm{~m} \text { below the ranch } \\
\text { road/impassable } \\
\text { culvert, proceeded } \\
300 \mathrm{~m} \text { down }\end{array}$ \\
\hline Otter_1A & Home Creek (B) & Down & D005/E005 & 45.54483 & -106.18717 & 952 & $\begin{array}{c}\text { Bottom of reach } \\
\text { began } \sim 500 \mathrm{~m} \text { above } \\
\text { the Otter Creek road } \\
\text { crossing, proceeded } \\
300 \mathrm{~m} \text { upstream }\end{array}$ \\
\hline
\end{tabular}

extreme high water year (avgerage yearly discharge 14.9 vs. 3.96 cfs in 2010). Therefore, we had to take advantage of sampling conditions as they presented themselves, sometimes not during the most ideal sampling periods (e.g., May visit @ 19 cfs between two high water pulses, Figure 1). Summer and fall visits were closer to base flow at 11 and $7 \mathrm{cfs}$, respectively. Habitat assessments, herpotofauna, macroinvertebrate and fish surveys were performed during the same site visit. In total, we surveyed 15 reaches for fish during the visits: four mainstem Otter Creek reaches (11 surveys) and two tributary streams (4 surveys). Fifteen macroinvertebrate samples were collected during the visits; neither survey was conducted at Threemile Creek in any season due to lack of surface water present. Spring and fall macroinvertebrate samples were collected outside of the MTDEQ recommend sampling time frame (June $1^{\text {st }}$-September $15^{\text {th }}$ ) (MTDEQ 2006), but this period 
was largely derived for mountain streams. All six a priori stream reaches were visually surveyed for amphibians or reptiles during all visits.

Figure 1. Discharge reported at the USGS gage in Ashland, MT. Arrows indicate sampling dates.

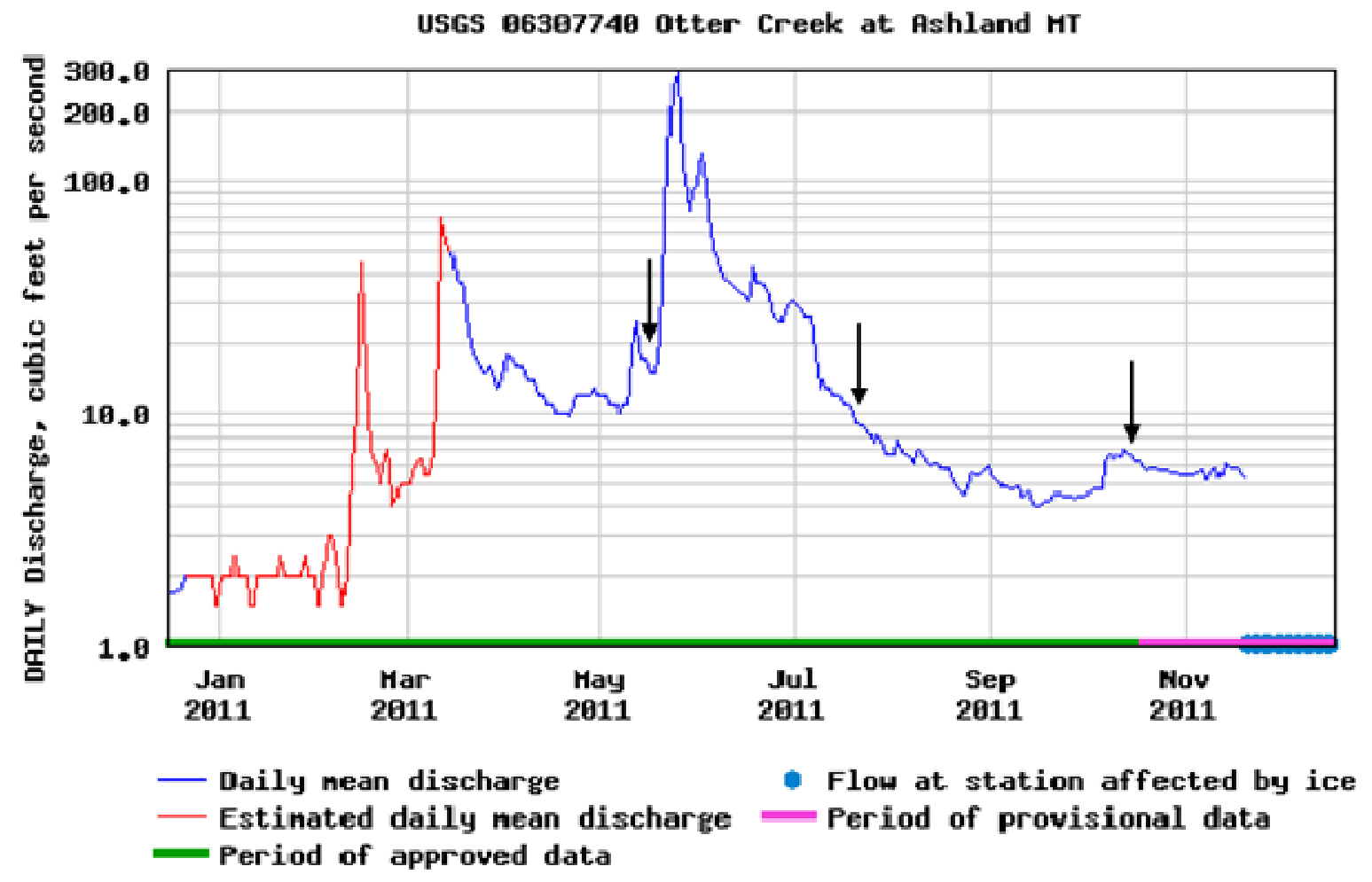

\section{Riparian Assessments}

The assessment stream reach was divided into 10 equally spaced transects according to BLM and EMAP protocols (BLM 2008b; Lazorchak et al. 1998). The downstream transect was marked (GPS, flagging and photo point) as the bottom of the reach and all ecological assessment protocols started from this point and continued upstream for $300 \mathrm{~m}$ (designated the assessment area or "AA") to the top of the reach which was also marked. Parameters recorded at each transect were: wetted width, three channel depth measurements, \% large woody debris and riparian shading. On-site habitat assessments were conducted using the rapid assessment protocol developed for the EPA by Barbour et al. (1999) with modifications for the BLM by the National Aquatic Assessment Team (scores 0-24) (BLM 2008). The process for determining Proper Functioning Condition followed Pritchard et al. (1993). Basic water parameters (temperature, $\mathrm{pH}$, conductivity) were recorded prior to biological sampling using a Horiba $\mathrm{H}-10$ water monitor, calibrated for the higher conductivity range. The Livestock Use Index ("Cowpie" CPI) was assessed by walking a randomly chosen $75 \mathrm{~m}$ reach on both sides of the stream channel in the riparian area within the assessment area and counting all the old and new cowpies (high CPI equals high cow usage). The goal of these evaluations is to characterize local reach geomorphology, riparian and 
in-stream habitat, and characteristics that influence aquatic community integrity. The sites ranking higher using these protocols are determined to have higher quality local-scale habitat. Habitat assessments were performed during the same visit as the biological sampling.

\section{Macroinvertebrate Communities}

Macroinvertebrate communities were sampled qualitatively from the 10 transects within the $300 \mathrm{~m}$ assessment reach using the EMAP Reach-Wide protocol (Lazorchak et al. 1998). Sampling started at the downstream transect (A) or \#10 in the BLM protocol, and proceeded upstream alternating sampling with the 500-micron D-frame net to the left, right or center of the stream channel, so a random sampling of all habitats is achieved (Figure 2). Ten multi-habitat kicks were composited from the net into a 20 liter bucket. All organisms and organic matter in the bucket

Figure 2. Macroinvertebrate EMAP Sampling procedure .

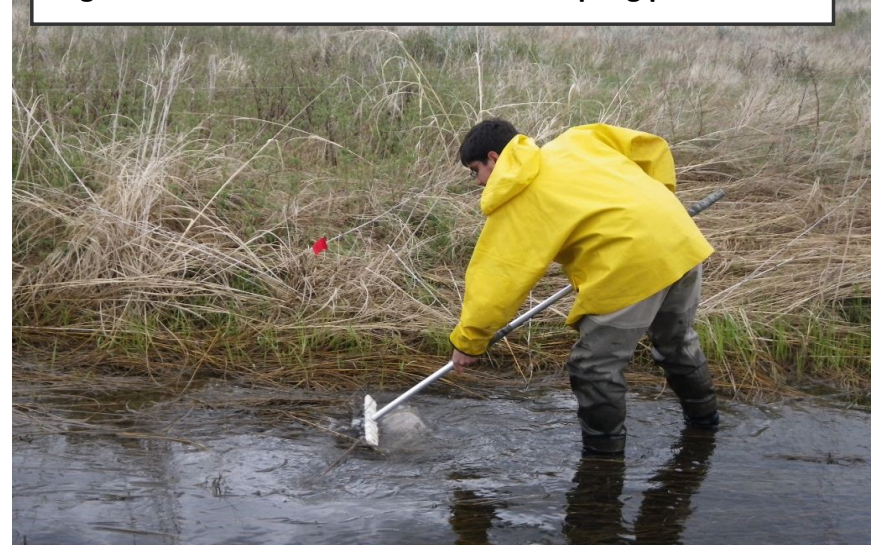
were elutriated from the inorganic portion and washed onto a 500-micron sieve. The inorganic portion was washed and examined until no further organics or organisms were present and discarded. The organic portion on the sieve was transferred to one or two 1 liter Nalgene bottles (unless field subsampling was needed), labeled and preserved in $95 \%$ ethanol and brought to the MTNHP lab in Helena for processing (sorting, identification and data analysis) following protocols outlined by the BLM (2008a) and MTDEQ (2006). Macroinvertebrates were identified to the lowest taxonomic level (MTDEQ 2006), counted, imported into EDAS (Jessup 2006), and biological metrics were calculated from the data using the Montana Department of Environmental Quality's newest multimetric macroinvertebrate (MMI) protocols (Jessup et al. 2005, Feldman 2006). Metric results were scored using the MTDEQ bioassessment criteria and each sample categorized as nonimpaired or impaired according to threshold values (Table 2). The macroinvertebrate $\mathrm{MMI}$ score is based upon a series of metrics that measure attributes of benthic

\section{Table 2. Impairment determinations from the MTDEQ MMI and $\mathrm{O} / \mathrm{F}$ (RIV/PACSI models}

\begin{tabular}{|c|c|c|c|}
\hline Ecoregion & RIVPACS & MMI & Impairment Determination \\
\hline Mountain & $\begin{array}{l}\geq 0.8 \text { or } \leq 1.2 \\
<0.8 \text { or }>1.2\end{array}$ & $\begin{array}{l}\geq 63 \\
<63\end{array}$ & $\begin{array}{l}\text { Wot impaired } \\
\text { Impaired }\end{array}$ \\
\hline Low Valley & $\begin{array}{l}\geq 0.8 \text { or } \leq 1.2 \\
<0.8 \text { or }>1.2\end{array}$ & $\begin{array}{l}\geq 48 \\
<48\end{array}$ & $\begin{array}{l}\text { Not impaired } \\
\text { lmpaired }\end{array}$ \\
\hline Eastern Plains & $\begin{array}{l}\geq 0.8 \text { or } \leq 1.2 \\
<0.8 \text { or }>1.2\end{array}$ & $\begin{array}{l}\geq 37 \\
<37\end{array}$ & $\begin{array}{l}\text { Not impaired } \\
\text { lmpaired }\end{array}$ \\
\hline
\end{tabular}

macroinvertebrate communities that are sensitive to condition changes in the stream (in the form of pollution or pollutants). The index score represents the condition of the macroinvertebrate community at the time the sample was collected within that past year. If the index score is below the impairment threshold, the individual metrics can be used to provide insight as to why the

communities are different from the reference condition (Barbour et. al 1999, Jessup et. al. 2005). 
The impairment threshold set by MTDEQ is $\mathbf{3 7}$ for the Eastern Plains Stream Index, thus any scores above this threshold are considered unimpaired.

\section{Fish and Amphibian Surveys}

Fish sampling within the 300m stream channel assessment reach was conducted with 6 and 9 meter straight seines in $25-30 \mathrm{~m}$ increments seining in a downstream direction toward the block seine (protocols outlined in Bramblett et al. 2005). Fish captured in a blocked section were transferred to holding buckets until the reach was completed, unless the reach was broken up by riffles, impassable or dry sections; in this case, fish were worked up and released within the section of capture. Fish holding in the buckets were identified to species (Holton and Johnson 2003), enumerated, examined for external anomalies (e.g. deformities, eroded fins, lesions, and

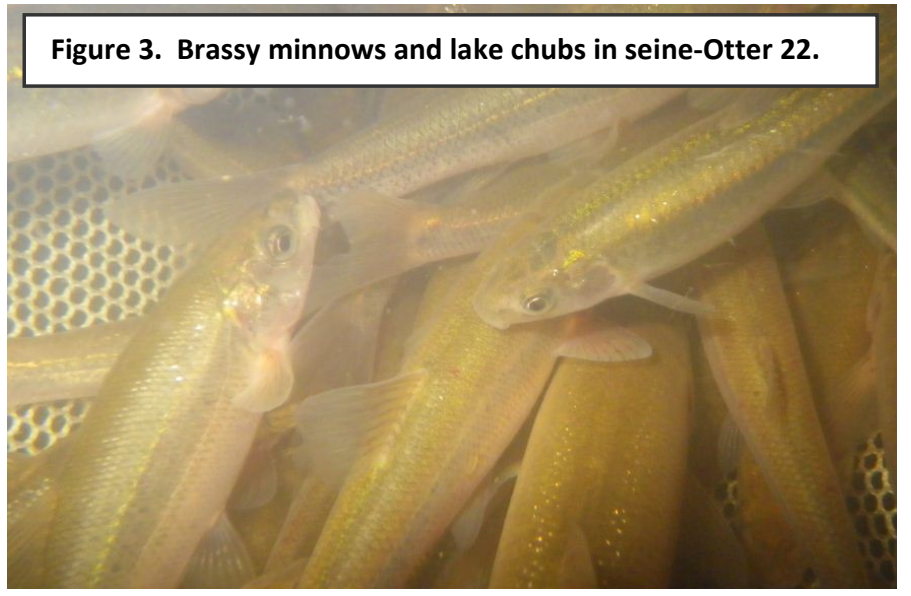
tumors), and then released. At least $10 \%$ of the individuals of a species were measured for total length in millimeters ( $T L \mathrm{~mm}$ ) to obtain size structure data. Young-of-theyear fish less than $20 \mathrm{~mm}(\mathrm{TL})$ were noted on the field sheet (not included in the totals) and released. Baited minnow traps were deployed and fished overnight (12 hour minimum) during the spring visits when seining conditions were toughest. Voucher specimens were only taken in the case of uncertain field identifications, and were preserved in $10 \%$ buffered formalin. These will be deposited with the Montana State University Collections. Adult amphibians or reptiles seen while seining or walking the designated stream reach were counted and recorded even if they were not captured in the seine.

Analysis of the sampled fish communities used Integrated Biotic Indices (IBI) designed for wadable prairie streams (Bramblett et. al 2005) and derived Observed/Expected (O/E) Fish Models (Stagliano 2011) to detect impairment in the biological integrity of the sites. The expected number of native fish species for a D005 classified reference stream is 2.5-3.75, while the number of fish for a C005 stream in 5.5-8.5 depending on watershed area, dividing the observed number of native fish species at a site by the expected number derives a percentage compared to reference 
condition $(>0.8$ or $80 \%=$ unimpaired) (Table 1 ). The IBI originally proposed by Karr (1981) involved the calculation of a series of 12 metrics evaluating different attributes of the fish community (i.e. species richness, tolerance to pollutants, trophic status) (Table 3). The 10 metrics used for the prairie streams were adjusted for watershed area to calculate an overall score between 0 and 100. Bramblett et al. (2005) did not propose threshold criteria for good, fair, and poor biological integrity for these scores. Therefore, we applied percentiles above the null criteria (no fish present score) at $>30 \%$ indicates good to excellent biological integrity, $10-30 \%$ fair/good biological integrity, $0-10 \%$ indicated poor to fair biological integrity and scores below the null are indicative of poor biological integrity or severely impaired.

Table 3. Fish metrics and classification of fishes captured during the Otter Creek Study (2011).

\begin{tabular}{|c|c|c|c|c|c|c|c|}
\hline Species & Scientific Name & $\underset{*}{\text { Trophic }}$ & $\begin{array}{c}\text { Feeding } \\
\text { Habitat } \uparrow\end{array}$ & $\begin{array}{c}\text { Repro } \\
\text { Guild } \neq\end{array}$ & $\begin{array}{c}\text { General } \\
\text { Tolerance } \\
* *\end{array}$ & $\begin{array}{c}\text { Origin } \\
+\dagger\end{array}$ & $\begin{array}{c}\text { Total } \\
\text { Length } \\
3 \text { years }\end{array}$ \\
\hline \multicolumn{8}{|l|}{ Catostomidae } \\
\hline White sucker & Catostomus commersoni & OM & $\mathrm{BE}$ & LO & TOL & $\mathrm{N}$ & 229 \\
\hline \multicolumn{8}{|l|}{ Cyprinidae } \\
\hline Common Carp & Cyprinus carpio & OM & $\mathrm{BE}$ & & TOL & I & 381 \\
\hline Brassy minnow & Hybognathus hankinsoni & $\mathrm{HB}$ & $\mathrm{BE}$ & & MOD & $\mathrm{N}$ & 81 \\
\hline Fathead Minnow & Pimephales promelas & OM & GE & TOL $\S$ & TOL & $\mathrm{N}$ & 76 \\
\hline Lake Chub & Couesius plumbeus & OM & GE & & MOD & $\mathrm{N}$ & 140 \\
\hline Sand Shiner & Notropis stramineus & OM & GE & LO & MOD & $\mathrm{N}$ & 61 \\
\hline \multicolumn{8}{|l|}{ Centrarchidae } \\
\hline Green Sunfish & Lepomis cyanellus & IC & GE & TOL $\S$ & TOL & I & 102 \\
\hline Pumpkinseed & Lepomis gibbosus & IC & GE & TOL $\S$ & MOD & I & 89 \\
\hline \multicolumn{8}{|l|}{ Ictaluridae } \\
\hline Black Bullhead & Ameiurus melas & IC & $\mathrm{BE}$ & TOL $\S$ & TOL & I & 152 \\
\hline $\begin{array}{l}* \mathrm{HB}=\text { herbivore }(>90 \% \\
\text { omnivore }(25-90 \% \text { plants } \\
\dagger \mathrm{BE}=\text { benthic; } \mathrm{GE}=\text { get } \\
\text { † } \mathrm{LO}=\text { Litho-obligate Rep } \\
\text { § Tolerant reproductive s } \\
* * \mathrm{INT}=\text { intolerant; } \mathrm{MO} \\
\dagger \dagger \mathrm{N}=\text { native; } \mathrm{I}-\text { introd }\end{array}$ & $\begin{array}{l}\text { olants or detritus); IC = invertivore } \\
\text { or detritus) } \\
\text { eralist; WC = water column: Browr } \\
\text { oductive Guild; Scott and Crossma } \\
\text { rategists are not litho-obligates, use } \\
=\text { moderately tolerant: } \mathrm{TOL}=\text { tole }\end{array}$ & $\begin{array}{l}\text { arnivore }(>2 . \\
\text { (1971); Scott } \\
\text { (1973); Pflie } \\
\text { arental care } \\
\text { ant; Barbour } \\
\text { son (2003) }\end{array}$ & $\begin{array}{l}\text { \% both inverte } \\
\text { ind Crossman } \\
\text { er (1997); Bat } \\
\text { spawning site } \\
\text { al. (1999); }\end{array}$ & $\begin{array}{l}\text { rates and ve } \\
\text { 1973); Becl } \\
\text { our et al. ( } \\
\text { Scott and C }\end{array}$ & $\begin{array}{l}\text { tebrates); IN = } \\
\text { er (1983) } \\
\text { 999) } \\
\text { rossman (1973) }\end{array}$ & Pflieger (1 & $\mathrm{OM}=$ \\
\hline
\end{tabular}

\section{Results}

We evaluated seven stream reaches in the study area: four Otter Creek mainstem sites were classified as Great Plains Perennial Prairie Stream types (C005), and the three tributaries were the Great Plains Intermittent Prairie Stream systems (D005, E005) (Stagliano 2005). Proper 
classification is important when determining biological integrity (Hawkins and Norris 2000) and expected species richness. The Intermittent Prairie Stream (E005) in Montana is naturally fishless about $80 \%$ of the time; therefore, absence of fish, in itself, should not be viewed as a biological impairment (Threemile and Tenmile Creek). Likewise, stream reaches of Otter Creek have become dry in previous years (Stagliano, personal observation 2005-2008), thus placing this stream section within the D005 classification. We have identified and characterized reference condition indicator assemblages for these ecosystem types previously (Stagliano 2005), and used these here to compare to our site-specific observed species.

Habitat Evaluations. Of the seven sampling reaches evaluated within the study area, we found three in Proper Functioning Condition (PFC) with a stable trend and four were Functional at Risk (FAR) (Table 7). Reasons that sites ranked FAR were due to structural habitat alteration by cattle with associated high CPI values (Home Creek $\left\{0 t t e r \_1 A\right\}$, Threemile Creek $\left\{0 t t e r \_3 m\right\}$ and Otter \#16-fall) (Figure 4) or anthropogenic stream manipulation (Otter Creek JT-Trussler and Otter Creek

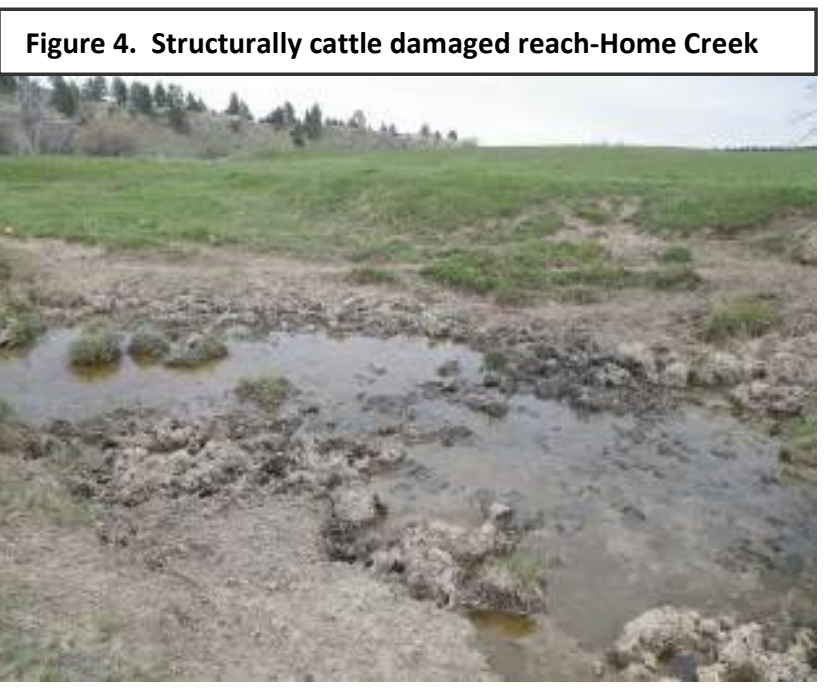
\#16). Highest site integrity scores using both the BLM Habitat and PFC Assessment methods were recorded at the Tenmile Creek (Otter_23) and Otter Creek \#22 (control-Denson reach) (Table 7). Point conductivity measurements recorded at all Otter Creek mainstem sites and tributaries across all seasons were above the threshold for

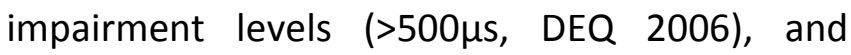
Home Creek site had visible signs of natural gas seepage from the sediments.

Macroinvertebrate Communities: Overall, 104 unique macroinvertebrate taxa were reported from the 15 macroinvertebrate assessment samples (Appendix B). One known Montana species of concern (SOC), the mayfly, Caenis youngi was collected in fair numbers at the control site, Otter Creek \#22. Stoneflies (P) were not present at any sites, so the EPT taxa per site usually consisted of two species of tolerant mayflies (E), and one or two species of caddisfly (T); the highest EPT richness at any site was six species at the Otter JT site spring (Table 4, Appendix B). Average 
macroinvertebrate taxa richness per site was 29.5 and the highest taxa richness was 41 taxa reported at the Otter Creek JT site. Using the MTDEQ multimetric index (MMI), four of the five sites (12 of 15 samples) were ranked non-impaired (good to excellent biological integrity), while all three samples from Tenmile Creek were ranked marginally impaired (Figure 5).

Table 4. Macroinvertebrate sample characteristics and various metrics used for the DEQ MMI.

\begin{tabular}{|lccccccccc|}
\hline Site ID & CollDate & $\begin{array}{c}\text { Total Ind. } \\
\text { ID'ed }\end{array}$ & $\begin{array}{c}\text { Total } \\
\text { Sample }\end{array}$ & $\begin{array}{c}\text { Total } \\
\text { Taxa }\end{array}$ & $\begin{array}{c}\text { Plains } \\
\text { MMI } \\
\text { Index }\end{array}$ & $\begin{array}{c}\text { EPT } \\
\text { Taxa }\end{array}$ & \% EPT & HBI & $\begin{array}{c}\text { \% Non- } \\
\text { Insect }\end{array}$ \\
\hline Otter_23 & $5 / 16 / 2011$ & 605 & 4,840 & 15 & 36.8 & 1 & 0.3 & 7.7 & 6.9 \\
Otter_23s & $7 / 17 / 2011$ & 515 & 2,060 & 12 & 35.2 & 0 & 0.0 & 7.3 & 15.2 \\
Otter_23f & $10 / 15 / 2011$ & 617 & 2,468 & 13 & 35.6 & 0 & 0.0 & 7.1 & 15.9 \\
OTTER_22 & $5 / 17 / 2011$ & 628 & 5,024 & 24 & 46.3 & 3 & 2.7 & 7.4 & 56.2 \\
OTTER_22s & $7 / 14 / 2011$ & 879 & 10,548 & 35 & 54.3 & 3 & 36.2 & 7.9 & 40.7 \\
OTTER_22f & $10 / 14 / 2011$ & 725 & 5,800 & 35 & 65.9 & 3 & 22.3 & 7.7 & 43.5 \\
OTTER_16 & $5 / 17 / 2011$ & 564 & 4,512 & 34 & 44.4 & 3 & 3.2 & 7.5 & 55.3 \\
OTTER_16s & $7 / 16 / 2011$ & 686 & 8,232 & 35 & 51.2 & 2 & 25.4 & 7.7 & 43.0 \\
OTTER_16f & $10 / 15 / 2011$ & 603 & 4,824 & 35 & 46.2 & 4 & 22.9 & 7.2 & 50.3 \\
OTTER_JT & $5 / 17 / 2011$ & 610 & 2,440 & 34 & 64.6 & 6 & 17.4 & 7.4 & 30.2 \\
OTTER_JTs & $7 / 18 / 2011$ & 605 & 3,630 & 28 & 65.8 & 5 & 18.2 & 7.5 & 37.7 \\
OTTER_JTf & $10 / 15 / 2011$ & 606 & 2,424 & 41 & 43.4 & 4 & 7.6 & 6.6 & 10.9 \\
OTTER_1A & $5 / 16 / 2011$ & 639 & 5,112 & 35 & 57.4 & 2 & 2.5 & 6.8 & 17.8 \\
OTTER_1As & $7 / 17 / 2011$ & 626 & 5,008 & 32 & 43.2 & 1 & 0.2 & 7.2 & 11.8 \\
OTTER_1Af & $10 / 14 / 2011$ & 617 & 4,936 & 35 & 37.9 & 1 & 0.3 & 7.0 & 21.7 \\
\hline
\end{tabular}

Figure 5. DEQ MMI scores across sites and seasons. Line is the impairment threshold at 37.

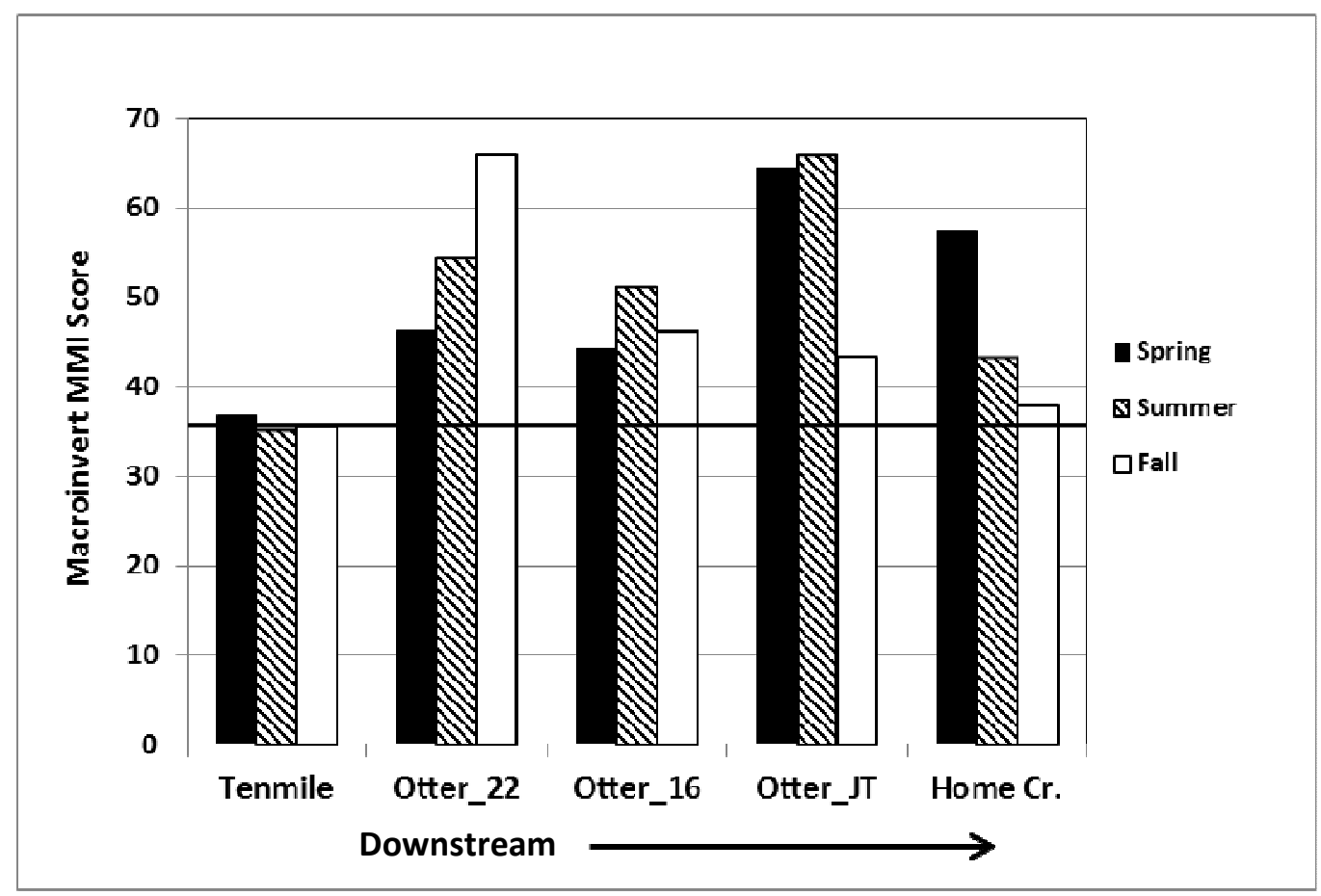


Stream sites that maintained flowing, connected water scored higher with the MMI than sites with interrupted pool areas. Overall, mainstem sites evaluated in the Otter Creek study received significantly higher macroinvertebrate MMI scores than those in the tributaries (T-test, $\mathrm{p}<0.01$ ). MMI's did not significantly differ on Otter Creek mainstem Pre-Impact Control, Impact or Downstream Sites (T-test, $p>0.05$ ), despite the fish communities reflecting a decrease in biotic integrity. No site had consistently high macroinvertebrate scores across all seasons.

Figure 6. Average MMI scores by site type. (a) = no baseline differences between treatments.

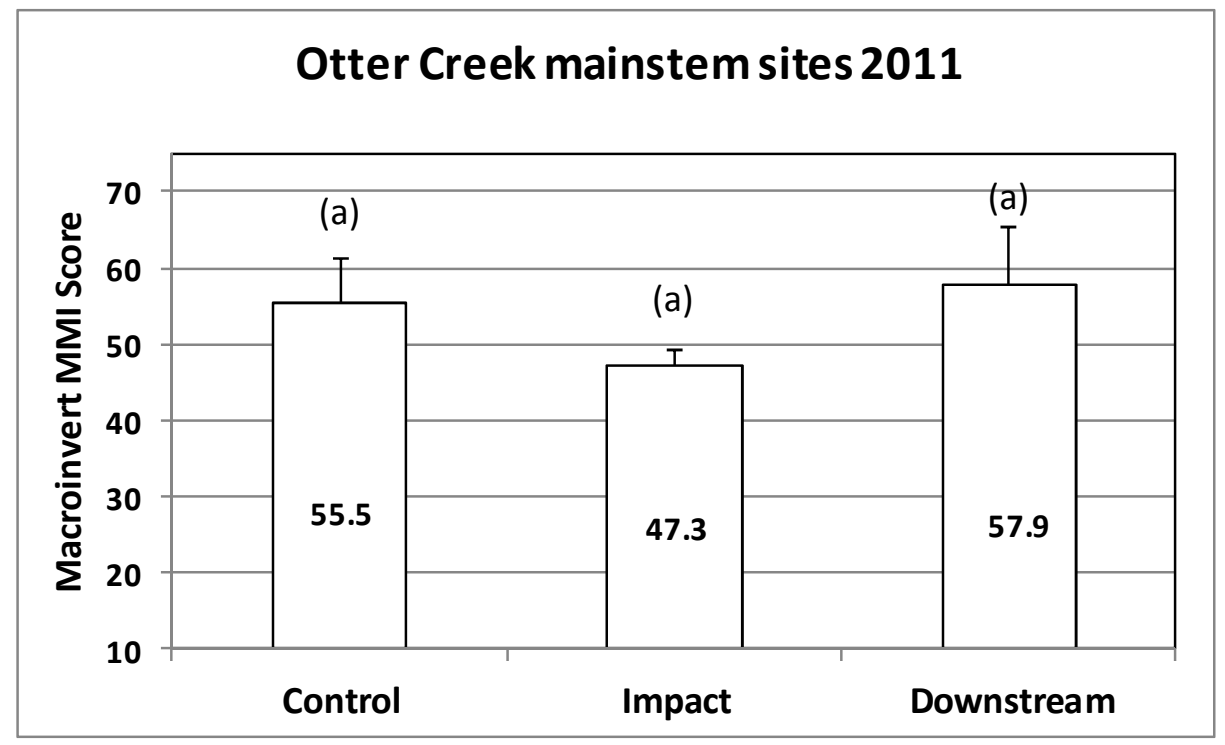

Fish Communities. Overall, nine fish species (five native/four introduced) were identified from 37,679 individuals collected from 15 site visits (Table 5). One potential species of concern (PSOC), the brassy minnow, was collected at five of six sites and in very high numbers at the control site, Otter 22. Dominance by brassy minnows and lake chubs at the upstream sites shifts to a tolerant fathead minnow and sand shiner dominated community at the downstream site, Otter JT (Table 5). Otter Creek site 16 was heavily infested by introduced species during the summer and fall visits representing $41 \%$ and $93 \%$ of the fish sampled, respectively. Average number of fish species collected at Otter Creek mainstem sites across all seasons was 6.5 ( $\pm 0.8 \mathrm{SE}$ ), while the tributary sites averaged 1.75 species (Table 5). All fish presence sites also reported at least one species of amphibian (Table 6). Lake chubs had the highest site occupancy rate at 93\% (14 of 15 visits) followed by fathead and brassy minnows at $80 \%$ (12 of 15 visits), but fathead minnows contributed to the highest proportion of individuals (56\%, see Table 5 ), followed by lake 
chubs at $17 \%$. The most diverse site in the study was Otter Creek JT site with nine species, while the most intact sites were Otter Creek Site \#22 at Denson's (four native spp.) and the Tenmile Creek spring survey (two native spp.).

Table 5. Fish abundance, IBI"s and O/E results for the 6 sites reporting fish. ns =not seined during visit (dry) or us =unseinable conditions. Underlined values are fish communities ranked biologically unimpaired.

\begin{tabular}{|c|c|c|c|c|c|c|c|c|c|c|c|c|c|c|c|c|c|c|c|}
\hline & \multicolumn{3}{|c|}{ OTTER_23 } & \multicolumn{3}{|c|}{ OTTER_22 } & \multicolumn{3}{|c|}{ OTTER_16 } & \multicolumn{3}{|c|}{ OTTER_2 } & \multicolumn{3}{|c|}{ OTTER_JT } & \multicolumn{3}{|c|}{ OTTER_1A } & \multirow[b]{2}{*}{ Total } \\
\hline & May & Jul & Oct & May & Jul & Oct & May & Jul & Oct & May & Jul & Oct & May & Jul & Oct & May & Jul & Oct & \\
\hline Black Bullhead* & 0 & ns & ns & 0 & 5 & 3 & 0 & 0 & 186 & us & 6 & 7 & 13 & 3 & 5 & 0 & 0 & 0 & 228 \\
\hline Brassy Minnow & 25 & ns & ns & 81 & 2400 & 588 & 104 & 549 & 51 & us & 154 & 364 & 143 & 30 & 65 & 0 & 0 & 0 & 4554 \\
\hline Common Carp* & 0 & ns & ns & 0 & 0 & 0 & 4 & 432 & 1314 & us & 14 & 49 & 20 & 213 & 138 & 0 & 0 & 0 & 2184 \\
\hline Fathead Minnow & 0 & ns & ns & 0 & 0 & 3 & 40 & 3 & 12 & us & 56 & 35 & 2008 & 2995 & 17810 & 10 & 5 & 1 & 22978 \\
\hline Lake Chub & 12 & ns & ns & 153 & 2785 & 1059 & 16 & 84 & 9 & us & 105 & 84 & 5 & 8 & 103 & 22 & 12 & 0 & 4457 \\
\hline Green Sunfish* & 0 & ns & ns & 0 & 0 & 3 & 0 & 0 & 6 & us & 0 & 0 & 3 & 3 & 3 & 0 & 0 & 0 & 18 \\
\hline Pumpkinseed ${ }^{\star}$ & 0 & ns & ns & 0 & 0 & 3 & 0 & 3 & 30 & us & 7 & 0 & 0 & 0 & 10 & 0 & 0 & 0 & 53 \\
\hline Sand Shiner & 0 & ns & ns & 0 & 0 & 0 & 0 & 0 & 0 & us & 22 & 0 & 38 & 25 & 2755 & 0 & 0 & 0 & 2840 \\
\hline White Sucker & 0 & ns & ns & 6 & 140 & 15 & 20 & 1 & 45 & us & 8 & 7 & 28 & 108 & 10 & 0 & 0 & 0 & 388 \\
\hline Total \# species & 2 & 0 & 0 & 3 & 4 & 7 & 5 & 6 & 8 & 0 & 8 & 6 & 8 & 8 & 9 & 2 & 2 & 1 & 9 \\
\hline Native Species & 2 & 0 & 0 & 3 & 3 & 4 & 4 & 4 & 4 & 0 & 5 & 4 & 5 & 5 & 5 & 2 & 2 & 1 & 5 \\
\hline Total Individuals & 37 & 0 & 0 & 240 & 5330 & 1674 & 184 & 1072 & 1653 & 0 & 372 & 546 & 2257 & 3384 & 20899 & 32 & 17 & 1 & 37,698 \\
\hline IBI & $\underline{75.6}$ & & & $\underline{66.1}$ & $\underline{67.3}$ & $\underline{69.2}$ & $\underline{62.3}$ & 50.7 & 44.4 & & $\underline{62.7}$ & $\underline{63.1}$ & 44.9 & 43.8 & 48.9 & $\underline{70.8}$ & $\underline{70.8}$ & 46.5 & \\
\hline O/E & $\underline{0.82}$ & & & $\underline{0.80}$ & $\underline{0.80}$ & $\underline{1.07}$ & 0.73 & 0.73 & 0.73 & & $\underline{0.91}$ & 0.73 & 0.59 & 0.59 & 0.59 & $\underline{0.82}$ & $\underline{0.82}$ & 0.41 & \\
\hline O/E \% & $\underline{81.6}$ & & & $\underline{80.0}$ & $\overline{80.0}$ & 106.7 & 72.7 & 72.7 & 72.7 & & $\underline{90.9}$ & 72.7 & 58.8 & 58.8 & 58.8 & $\overline{81.6}$ & $\overline{81.6}$ & 40.8 & \\
\hline
\end{tabular}


Using the Prairie Fish IBI, 9 of the 15 fish sites were ranked non-impaired (good biological integrity), two were slightly impaired (moderate integrity), three were moderately impaired (poor biotic integrity) and the Home Creek fall survey was ranked severely impaired (Figure 7). The O/E models tracked the IBI scores quite well at most sites (13 of 15), except two where the O/E ranked the site as slightly impaired and the IBI ranked the sites as non-impaired (Figure 8).

Figure 7. Fish IBI scores across sites and seasons. Line is the null IBI threshold (fish absent).

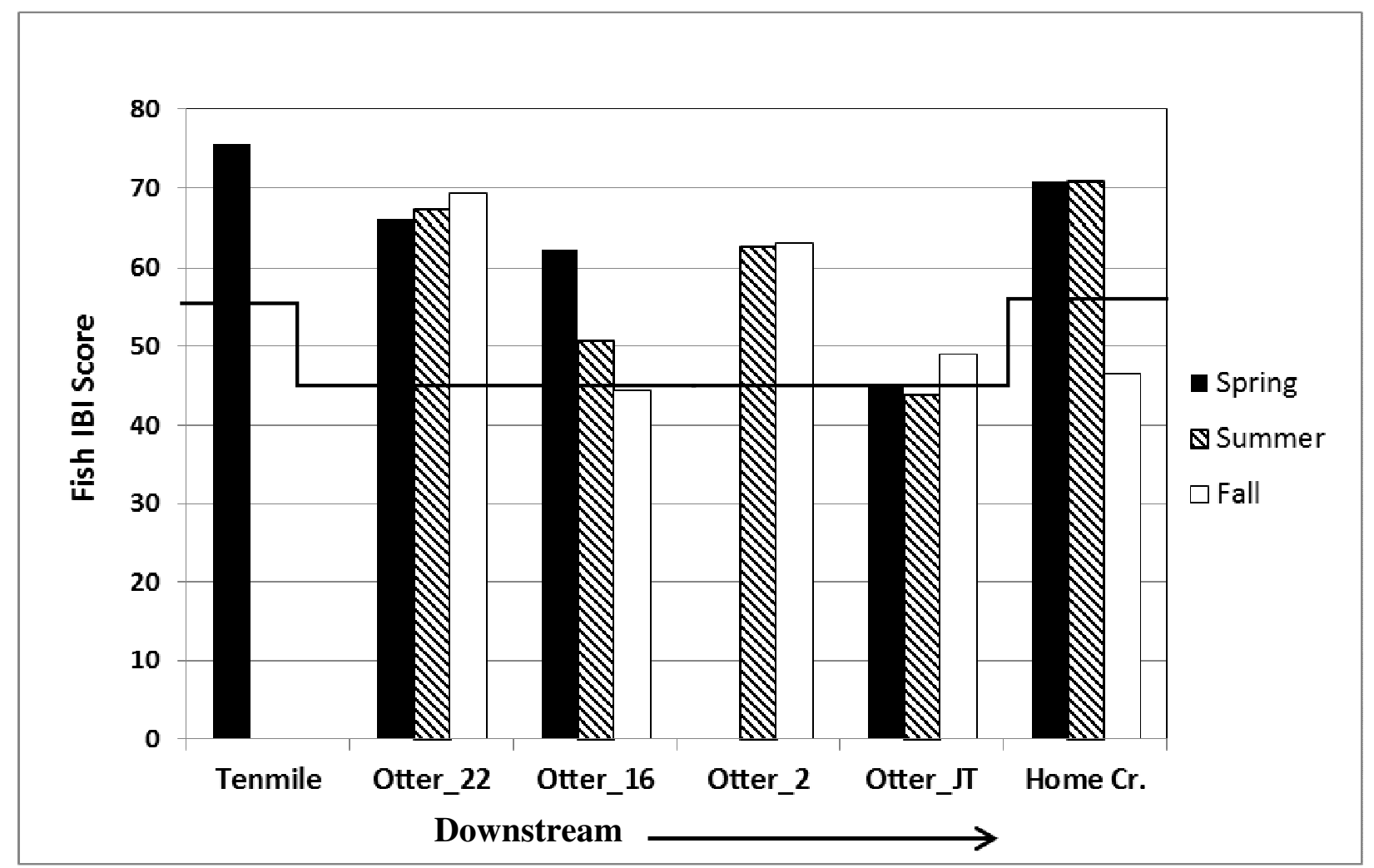

Fish IBI's decreased going downstream on Otter Creek, and the Pre-Impact Control Site scored significantly higher than either the Impact or Downstream sites (T-test, $p=0.05$ ) (Figure 9). Within the Great Plains Intermittent Prairie Streams, the species expected to occur most often at reference condition sites are the fathead minnow and brook stickleback, but the upper Tongue and Powder River Basins are slightly out of the range of this latter species; therefore, we did not collect them or expect them to occur at these sites and revised the Observed /Expected $(O / E)$ Fish Model predictors accordingly. The O/E scores agreed with the IBI scores in most cases, 
except for the Otter Creek stream reaches that could be classified as Perennial vs. Intermittent Prairie Streams (CO05) (Table 5).

Figure 8. Fish IBI compared to O/E model (\%) scores across sites and seasons.

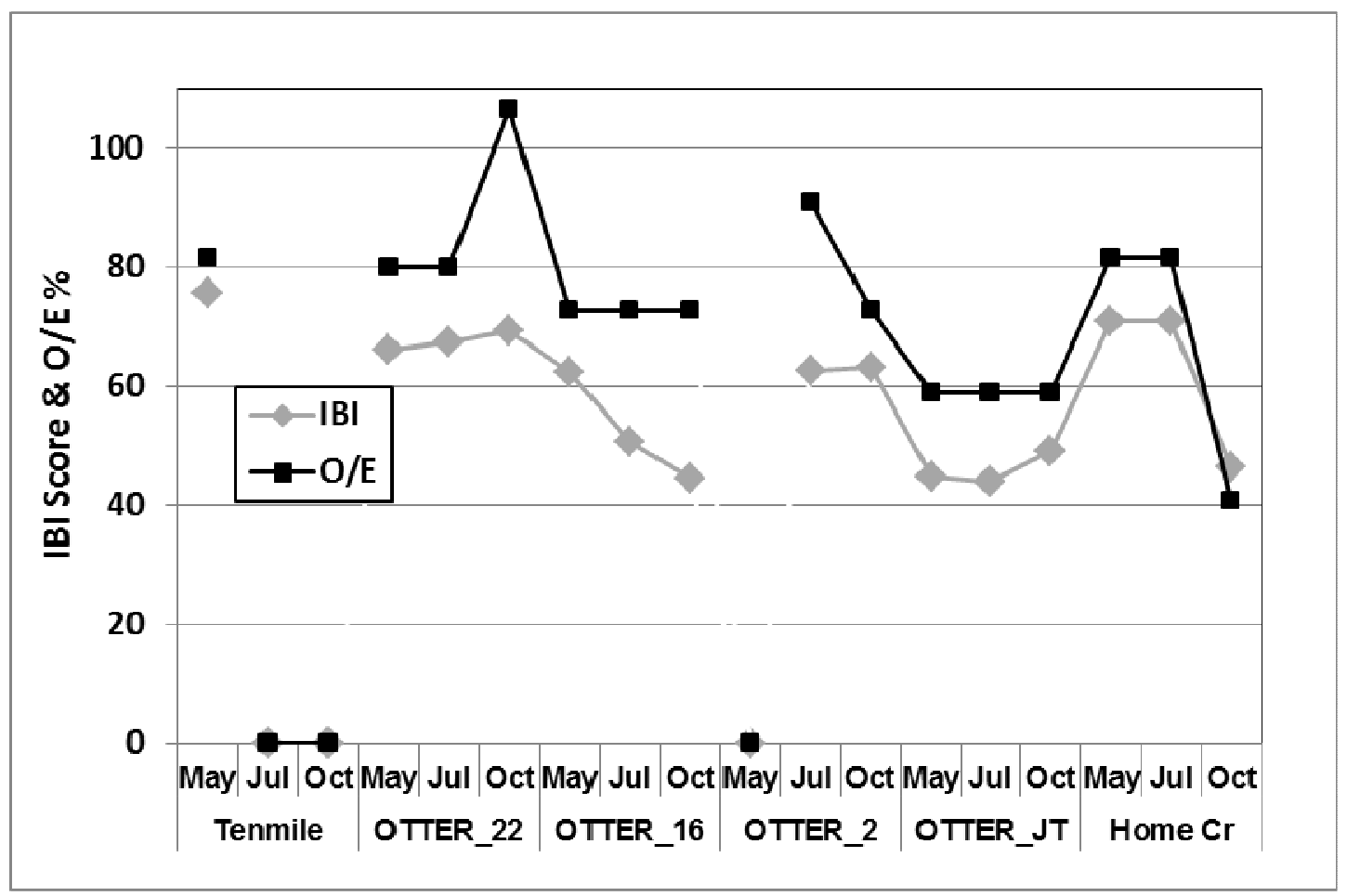

Figure 9. Average fish IBI scores by site type. $(\mathrm{a})=$ no baseline differences between treatments.

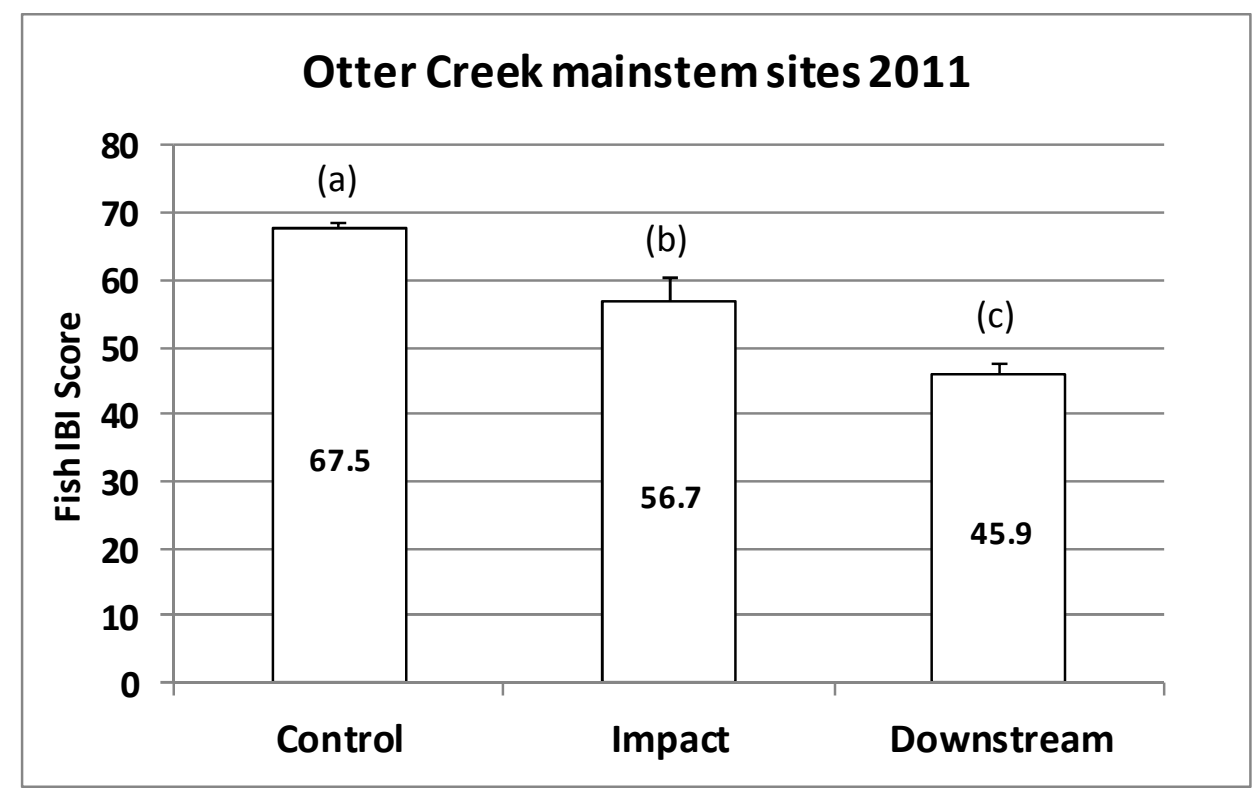


Amphibian and Reptile Incidentals. Overall, eight herpetofauna species were observed, collected in dipnets/seines or incidentally recorded in conjunction with the fish, habitat and macroinvertebrate surveys. Otter Creek \#22 and \#16 were the most diverse sites reporting five herpetofuana species cumulatively across all seasons. We reported four amphibian species, of which Woodhouse's Toad (Bufo woodhousii) had the highest site occupancy, occurring at six of seven sites, followed by the Northern Leopard Frog (Rana pipiens) and Tiger Salamander (Ambystoma tigrinum) (Figure 10) recorded at five and four sites, respectively (Table 6). Boreal Chorus Frog (Pseudacris maculata) was detected vocally calling at three sites during the spring visits only and one incidental sighting during a
Table 6. Vertebrates (Species Code) recorded during the Otter Creek Surveys. Frequency of Occurrence (FO) was calculated from the \# of site visits detected/ \# of visits capable for detection: Herps $(n=21)$ and Fish $(n=15) .{ }^{*}=$ Introduced Species

\begin{tabular}{|l|c|c|}
\hline \multicolumn{1}{|c|}{ Herpetofauna } & Visits Det & FO \\
\hline Woodhouse's Toad (BUWO) & 9 & 0.43 \\
\hline Northern Leopard Frog (RAPI) & 7 & 0.33 \\
\hline Tiger Salamander (AMTI) & 5 & 0.24 \\
\hline Boreal Chorus Frog (PSMA) & 4 & 0.19 \\
\hline Painted Turtle (CHPI) & 4 & 0.19 \\
\hline Western Rattlesnake (CRVI) & 4 & 0.19 \\
\hline Snapping Turtle (CHSE) & 2 & 0.10 \\
\hline Terrestrial Gartersnake (THEL) & 2 & 0.10 \\
\hline \multicolumn{1}{|c|}{ Fish } & & \\
\hline Lake Chub (LACH) & 14 & 0.93 \\
\hline Fathead Minnow (FAMI) & 12 & 0.80 \\
\hline Brassy Minnow (BRMI) & 12 & 0.80 \\
\hline White Sucker (WHSU) & 10 & 0.67 \\
\hline Black Bullhead* (BLBU) & 8 & 0.53 \\
\hline Common Carp* (CARP) & 8 & 0.53 \\
\hline Green Sunfish* (GRSU) & 5 & 0.33 \\
\hline Pumpkinseed* (PUMP) & 5 & 0.33 \\
\hline Sand Shiner (SASH) & 4 & 0.27 \\
\hline
\end{tabular}

summer visit. We also recorded four reptile species (in order of site occurrence): Western Rattlesnake (Crotalus viridis), Painted Turtle (Chrysemys picta) (Figure 10), Terrestrial Garter Snake (Thamnophis elegans) and Snapping Turtle (Chelydra serpentina) (SOC).

Figure 10. Tiger Salamander (left) from Home (Otter_1A) and Painted Turtle from OtterJT (right).
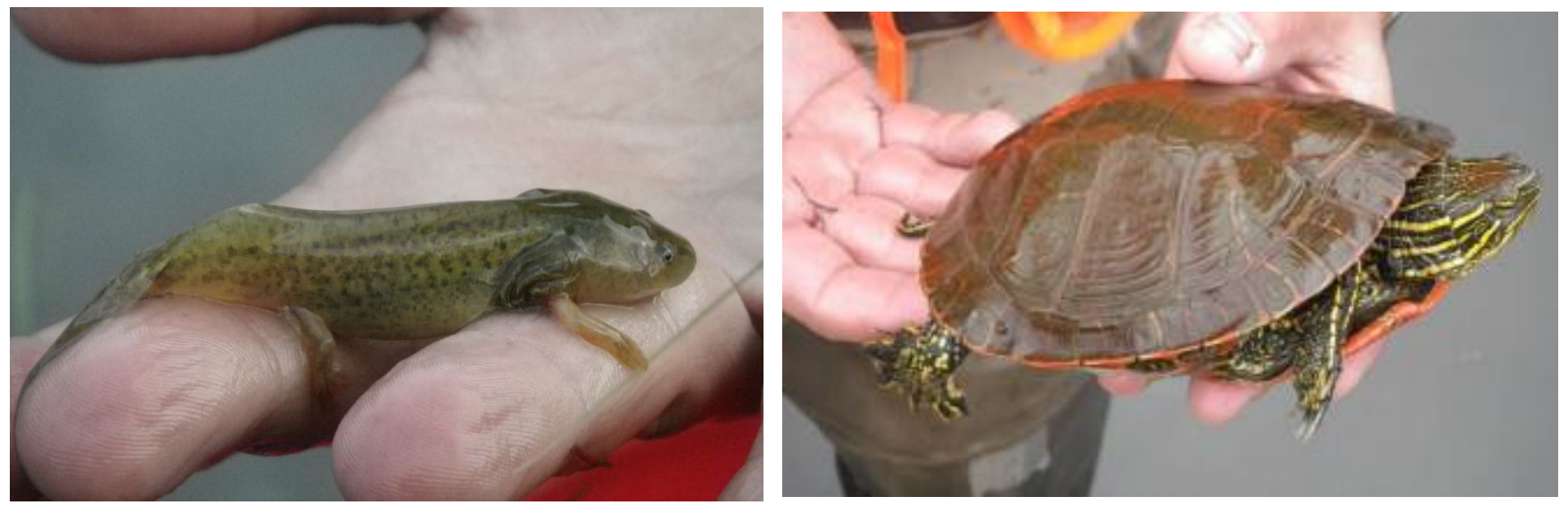


\section{Conclusions}

The aquatic community sampling sites chosen for pre-impact baseline data were representative of the range of stream classes found in the Otter Coal Tracts project area: Ephemeral, Intermittent and Perennial Prairie Streams. Despite this being an unusually high water year for the region, stream communities that we sampled across the seasons encompassed the range of expected species to occur in these stream types, and fish and macroinvertebrate community assessment scores were similar to biological assessments performed in previous years (Table 7).

Table 7. Otter Creek Temporal Habitat Scores, Fish IBIs and MMIs. Metric Score Ranks (+): unimpaired, (-): impaired, (=): marginal, $(\mathrm{na})=$ not applicable, taxa group not collected. Spatial relationship in river miles $(\mathrm{rm})$ to them adjacent Coal Tract Study Site

\begin{tabular}{|c|c|c|c|c|c|c|c|c|}
\hline Site Code & Site Name & $\begin{array}{c}\text { Spatial } \\
\text { Relation }\end{array}$ & Date & $\begin{array}{l}\text { BLM } \\
\text { PFC }\end{array}$ & $\begin{array}{c}\text { BLM } \\
\text { Hab } \\
\text { Score } \\
\end{array}$ & $\begin{array}{c}\text { Fish } \\
\text { IBI }\end{array}$ & $\begin{array}{c}\text { MT } \\
\text { MMI }\end{array}$ & $\begin{array}{c}\text { Metric } \\
\text { Score } \\
\text { Ranks } \\
\end{array}$ \\
\hline ATG_203 & Otter Creek at Camp Creek Road & $\sim 16 \mathrm{rm}$ ups & $7 / 11 / 2010$ & PFC & 20 & 50 & 58.4 &,,+++ \\
\hline ATG_235 & South Fork Taylor Creek & $\sim 13 \mathrm{rm}$ ups & $7 / 11 / 2010$ & PFC & 22 & 71 & 73.5 &,,+++ \\
\hline ATG_202 & Otter Creek at Taylor Creek Road & $\sim 12 \mathrm{rm}$ ups & $7 / 11 / 2010$ & PFC & 19 & 60 & 36.3 &,,++- \\
\hline ATG_CCC & Otter Creek at CCC Camp USFS & $\sim 3$ rm ups & $7 / 11 / 2010$ & PFC & 19 & 58 & 37.9 &,,$++=$ \\
\hline ATG_201 & Otter Creek at Tenmile Cr Road & $100 \mathrm{~m}$ ups & $7 / 11 / 2010$ & PFC & 19 & 52 & 44.6 &,$+=,+$ \\
\hline OTTER_23 & TenmileCreek @ Denson Ranch & $0 \mathrm{rm}$ & $5 / 10 / 2011$ & FAR & 16 & 75 & 36.8 &,,-+- \\
\hline OTTER_23 & Tenmile Creek@ Denson Ranch & $0 \mathrm{rm}$ & $7 / 18 / 2011$ & FAR & 17 & na & 35.2 &,- na , - \\
\hline OTTER_23 & Tenmile Creek @ Denson Ranch & $0 \mathrm{rm}$ & $10 / 10 / 2011$ & FAR & 17 & na & 35.6 &,- na ,- \\
\hline OTTER_22 & Otter Creek at Tenmile Cr Road & $0 \mathrm{rm}$ & $5 / 10 / 2011$ & PFC & 22 & 66.1 & 46.3 &,,+++ \\
\hline OTTER_22 & Otter Creek at Tenmile Cr Road & $0 \mathrm{rm}$ & $7 / 18 / 2011$ & PFC & 22 & 67.3 & 54.3 &,,+++ \\
\hline OTTER_22 & Otter Creek at Tenmile Cr Road & $0 \mathrm{rm}$ & $10 / 10 / 2011$ & PFC & 22 & 69.2 & 65.9 &,,+++ \\
\hline OTTER_16 & Otter Creek at Ranch Road x & $0 \mathrm{rm}$ & $5 / 19 / 2011$ & PFC & 19 & 62.3 & 44.4 &,,+++ \\
\hline OTTER_16 & Otter Creek at Ranch Road x & $0 \mathrm{rm}$ & $7 / 16 / 2011$ & PFC & 19 & 50.7 & 51.2 &,,+-+ \\
\hline OTTER_16 & Otter Creek at Ranch Road x & $0 \mathrm{rm}$ & $10 / 15 / 2011$ & FAR & 18 & 44.4 & 46.2 & $=,-,+$ \\
\hline OTTER_2 & Otter Creek at Ranch Road x & $0 \mathrm{rm}$ & $7 / 16 / 2011$ & FAR & 17 & 62.7 & na & $=,+$, na \\
\hline OTTER_2 & Otter Creek at Ranch Road x & $0 \mathrm{rm}$ & $10 / 15 / 2011$ & FAR & 17 & 63.1 & na & $=,+$, na \\
\hline YL_S7OREM & Otter Creek at 3 mile creek & $400 \mathrm{~m}$ dns & $7 / 18 / 2000$ & na & na & na & 59.7 & na , na , + \\
\hline OTTER_JT & Otter Creek J Trusler site & $0 \mathrm{rm}$ & $5 / 17 / 2011$ & PFC & 19 & 44.9 & 64.6 &,,+-+ \\
\hline OTTER_JTs & Otter Creek J Trusler site & $0 \mathrm{rm}$ & $7 / 18 / 2011$ & PFC & 19 & 43.8 & 65.8 &,,+-+ \\
\hline OTTER_JTf & Otter Creek J Trusler site & $0 \mathrm{rm}$ & $10 / 15 / 2011$ & PFC & 19 & 48.9 & 43.4 &,,+-+ \\
\hline YL_S0070dn & Otter Creek below Trusler site & $300 \mathrm{~m}$ dns & $6 / 2 / 2003$ & na & na & na & 56.2 & na , na , + \\
\hline OTTER_1A & Home Creek & $0 \mathrm{rm}$ & $5 / 16 / 2011$ & FAR & 11 & 70.8 & 57.4 &,,-++ \\
\hline OTTER_1A & Home Creek & $0 \mathrm{rm}$ & $7 / 17 / 2011$ & FAR & 12 & 70.8 & 43.2 &,,-++ \\
\hline OTTER_1A & Home Creek & $0 \mathrm{rm}$ & $10 / 15 / 2011$ & FAR & 13 & 46.5 & 37.9 &,,$--=$ \\
\hline
\end{tabular}

Biotic integrity of the upstream control reaches of Otter Creek was initially higher during this baseline study. One extraordinary finding was the high density and large biomass of fish inhabiting the stream reach below Trusler's Ranch road crossing $(20,000$ fish in the $300 \mathrm{~m}$ reach 
fall survey, $15 \mathrm{fish} / \mathrm{m} 2)$; this is largely an artifact of the impassible culvert located here and the fish "stacking up" downstream of this barrier. Density dependent fish anomalies (lesions and parasites, i.e., yellow grub and anchor worm) are prevalent at this site, indicating the fish are likely experiencing stress from overcrowding. Benthic macroinvertebrate densities at this site are low, but, more diverse than other sites, indicating that the fish may be consuming large portions of the available insect production having a top-down community effect. Outside of coal extraction, threats to this stream system, which can be managed, include grazing and livestock use around the riparian areas. Moderate occurrences in these basins can have strong local effects resulting in sedimentation, stream widening at cattle crossings and loss of functional channel hydrology. Introductions of game (green sunfish, bullheads or pumpkinseeds) or forage fish in stock ponds anywhere in the watershed can pose potential problems for native fish as these introduced fish become permanent residents, outcompete or prey upon the native fish and contribute to overall community degradation. Diverse aquatic communities with high biological integrity are usually correlated with good riparian condition and habitat quality (Allen et al. 1997). Thus, effective riparian zone management of cattle grazing would contribute to intact vegetation buffers and less sediment in the aquatic environment (George et al. 2002). In this study, macroinvertebrate communities ranked few sites as impaired, even those with an obvious impaired riparian condition, but the effectiveness of macroinvertebrates in assessing prairie stream impairment is still under debate in Montana. Community results from the habitat, fish and macroinvertebrate surveys combined to rank the following sites from highest biological integrity to lowest within their aquatic ecological classification codes:

Northwestern Great Plains Perennial Prairie Stream (AES code C005)-1) Otter Creek \#22, 2) Otter Creek \#2, 3) Otter Creek \#16, 4) Otter Creek -J Trusler site 


\section{Site Photos}

Otter Creek \#22 (control) during spring visit: pools (left) and riffle (right)
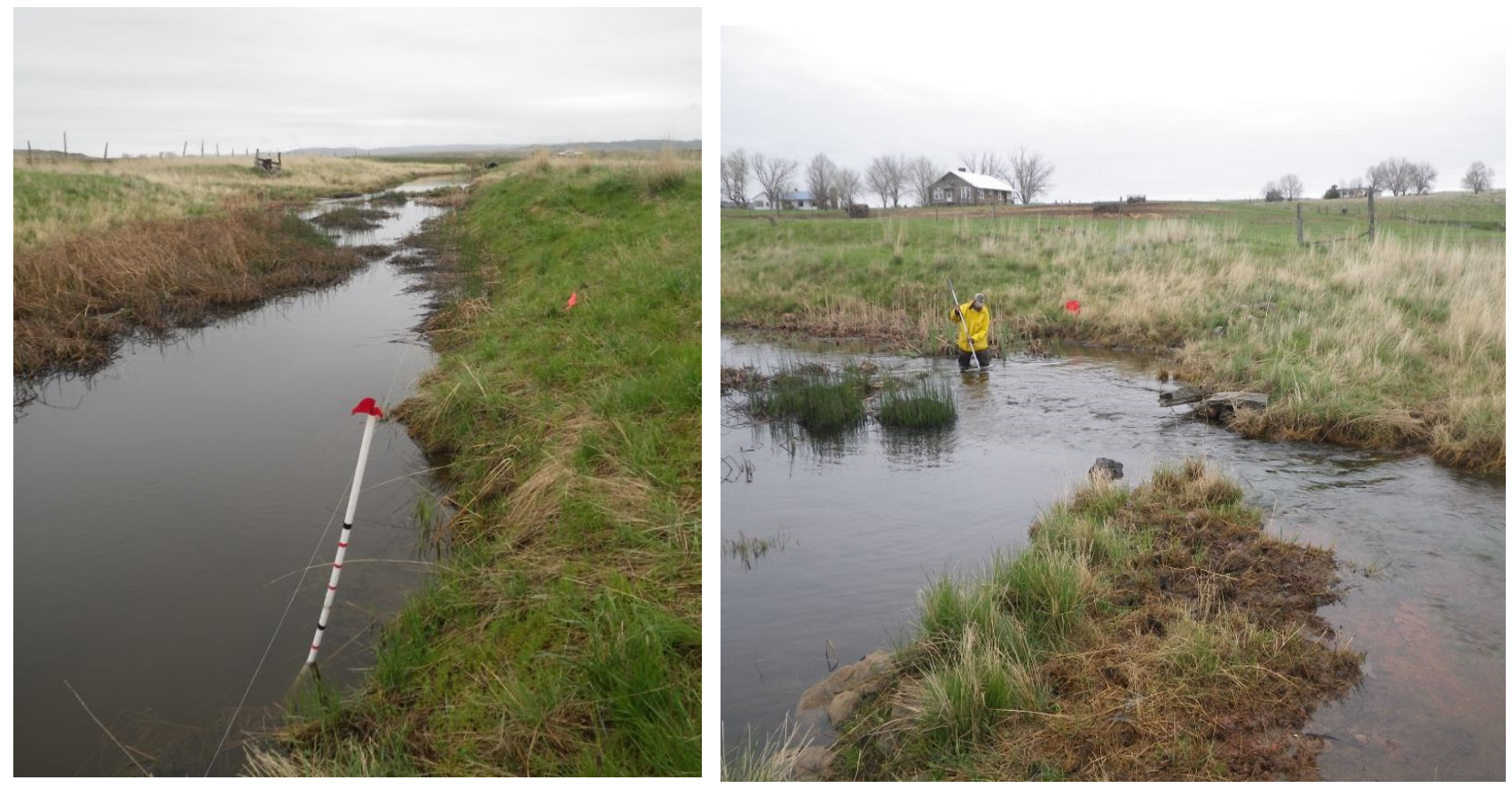

Otter Creek \#2 (impact): fall visit looking downstream to block net (left) and upstream (right).
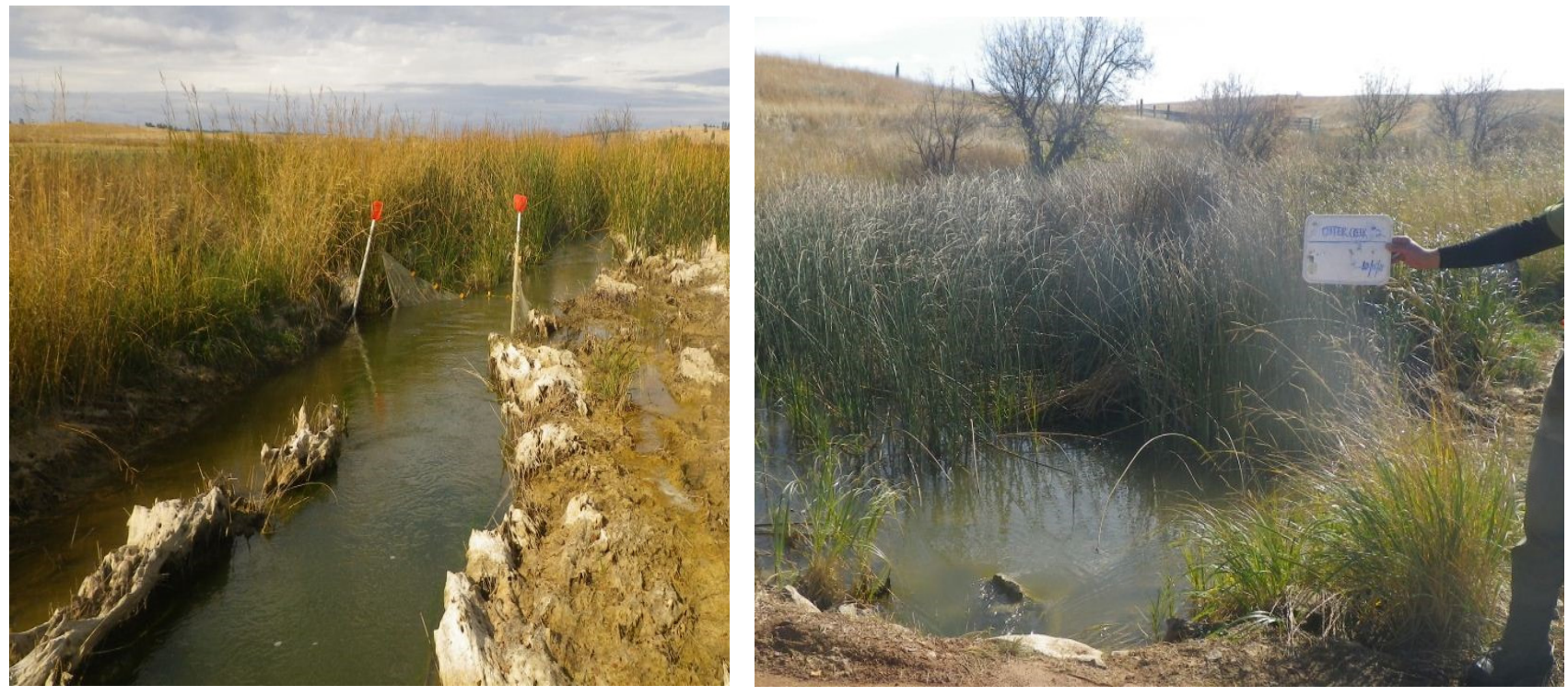


\section{Site Photos}

Otter Creek \#16 (impact) spring visit: pool (left) and shallow stream crossing (right).
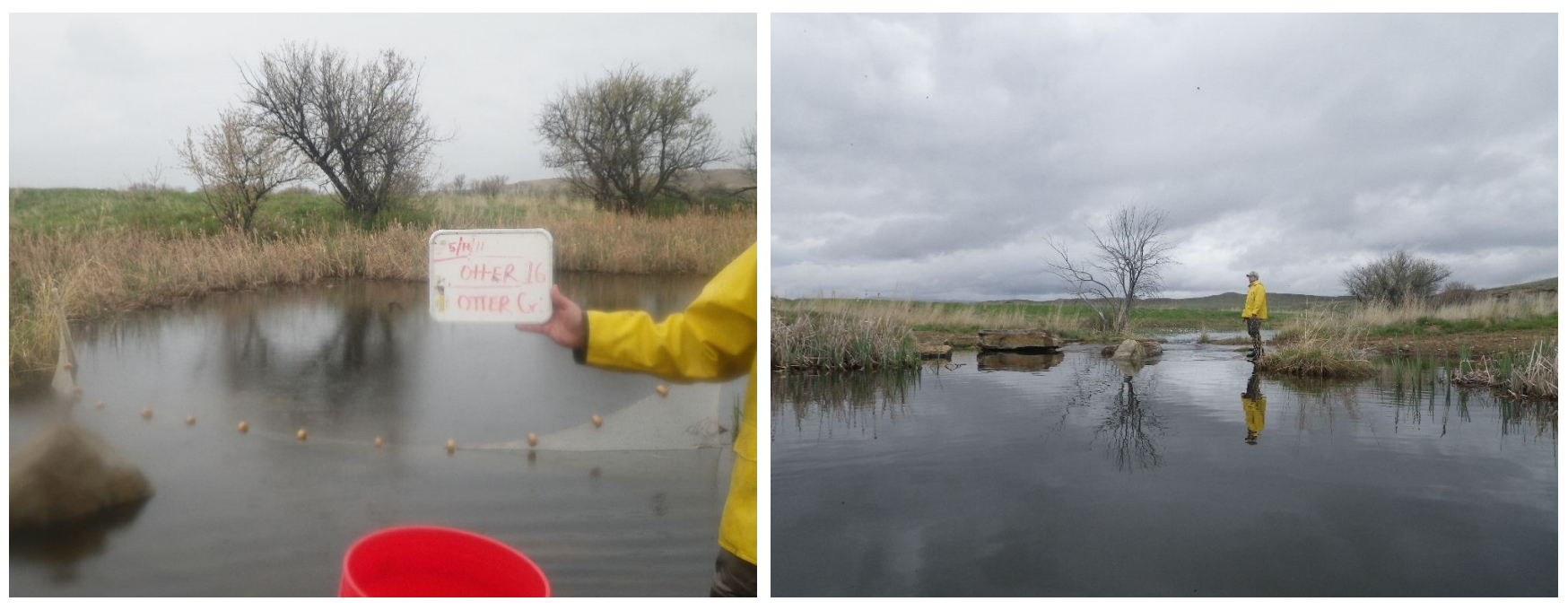

Otter Creek \#16 (impact) during summer visit: downstream pool (left) and drill trucks using the stream crossing (right).
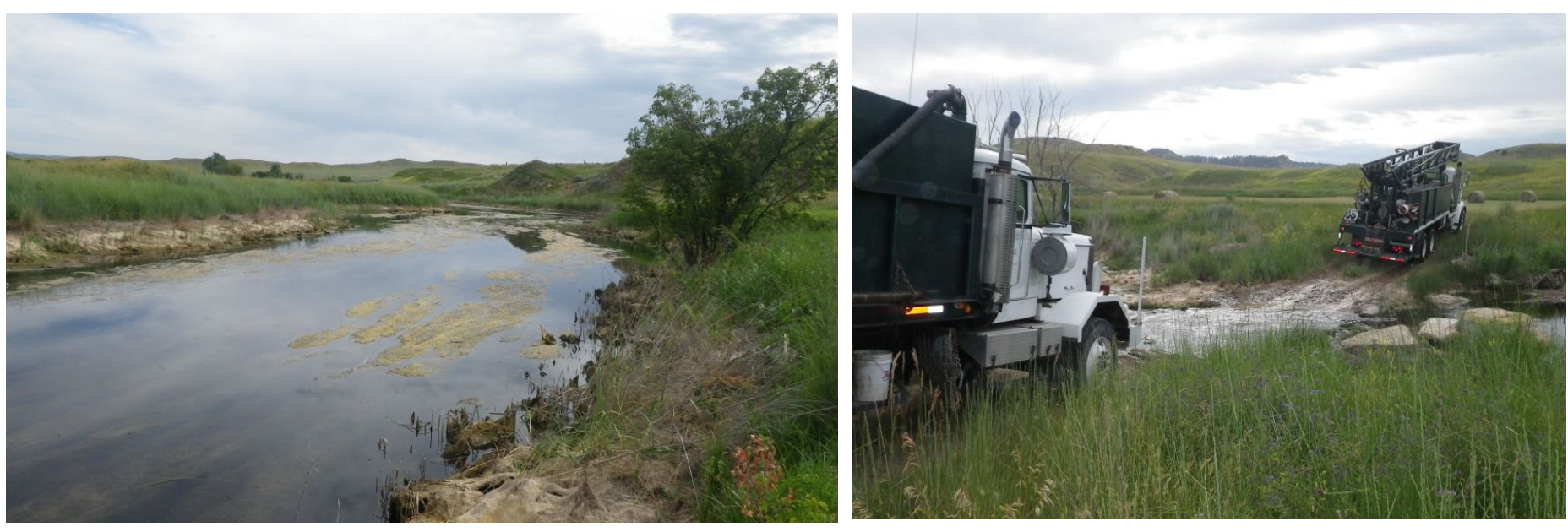


\section{Site Photos}

Otter Creek JT (downstream): summer visit looking downstream (left) and upstream (right)
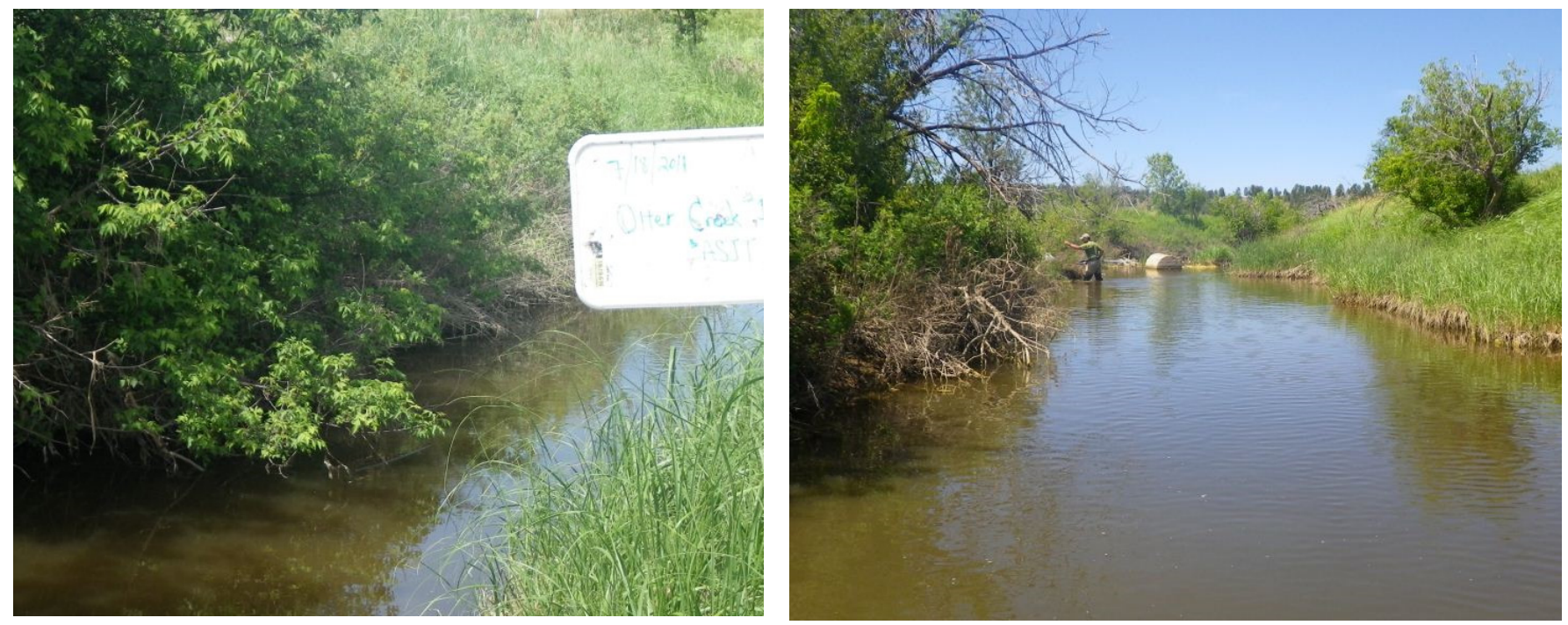

Northwestern Great Plains Intermittent Prairie Stream-(AES code D005)-1) Home Creek 1A, 2)

Tenmile Creek,

Home Creek (Otter 1A) during the Spring (left) and Summer (right) Visits
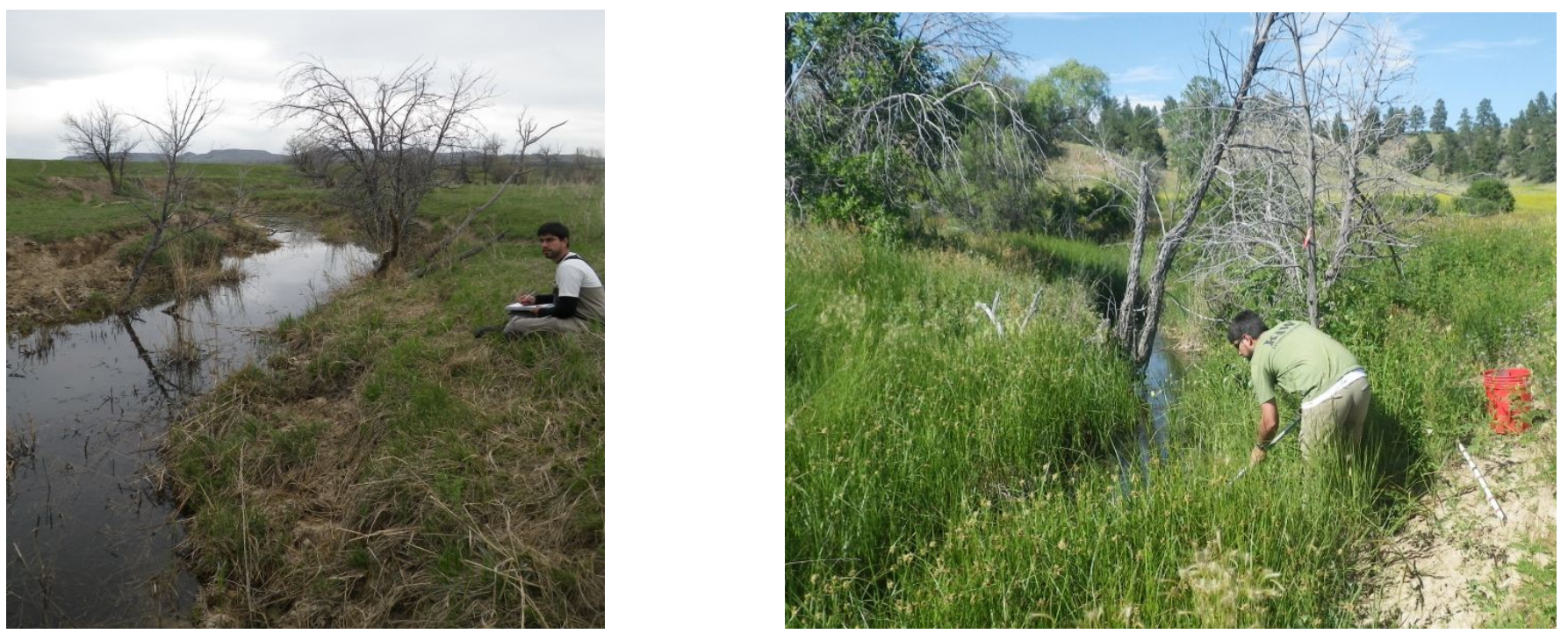


\section{Site Photos}

Tenmile Creek (Otter_23) in the Spring (left) and Summer (right)
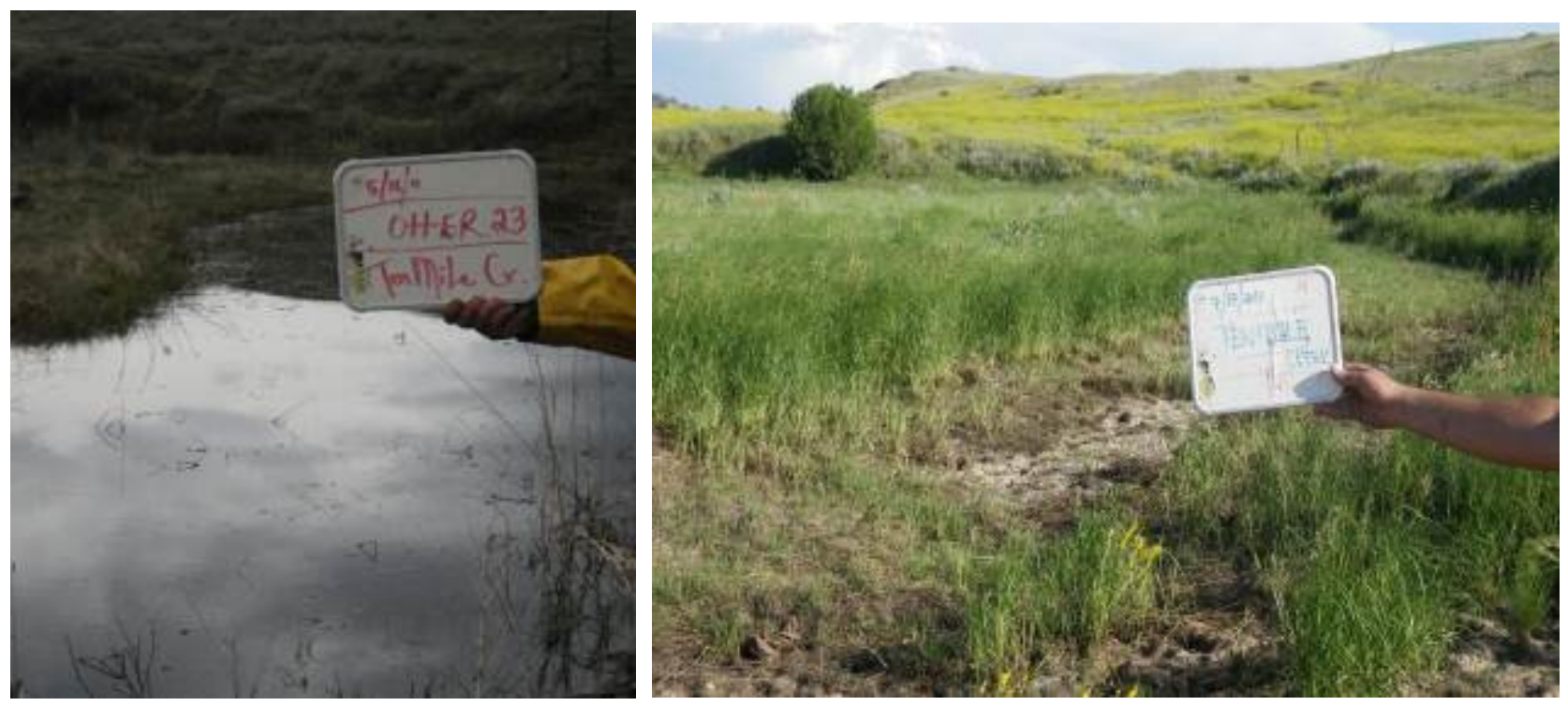

Great Plains Intermittent Fishless Prairie Stream (AES code E005)-1) Threemile Creek Site Photos: Threemile Creek (Otter $3 \mathrm{~m}$ ) during the spring (left) and summer (right) Visits

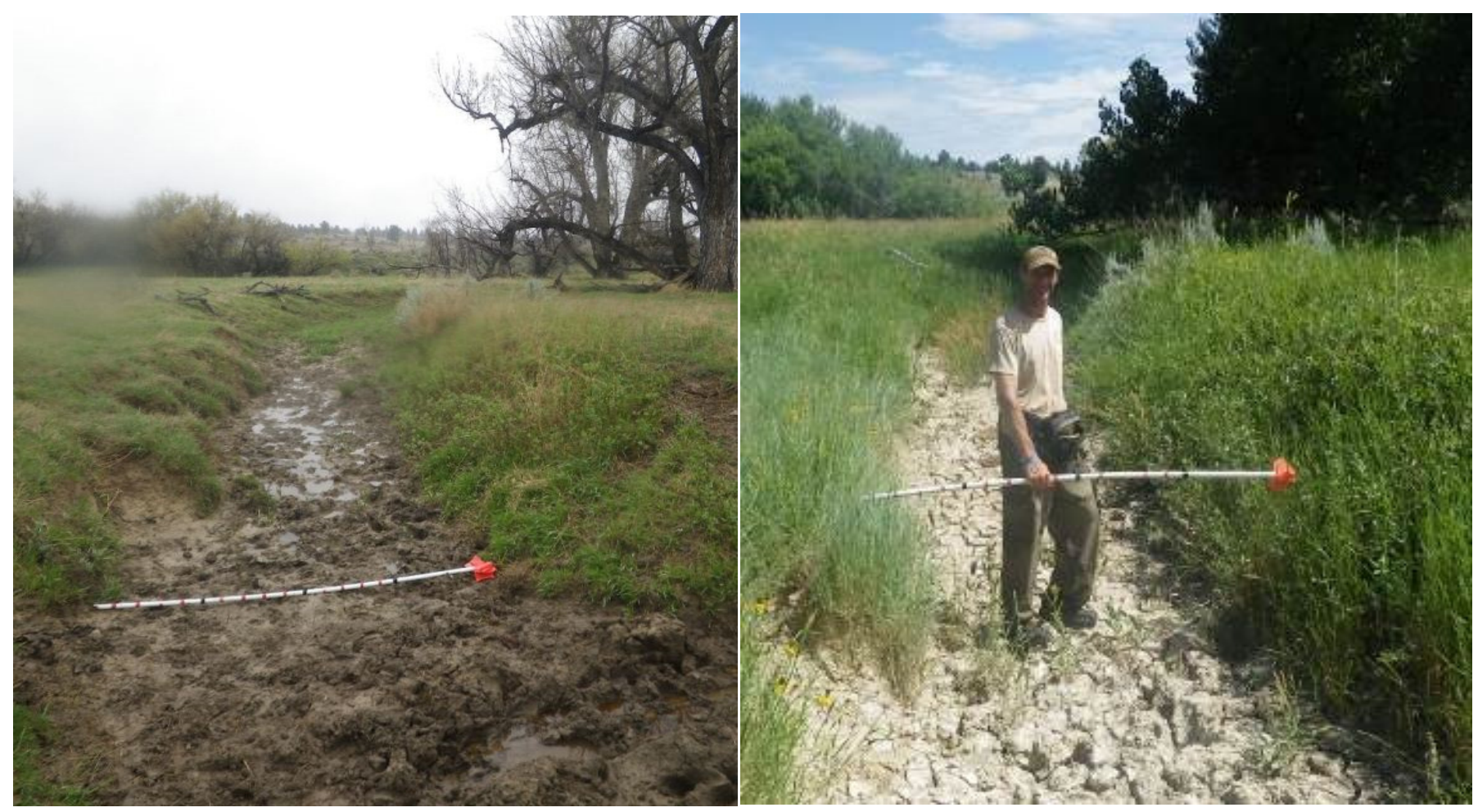




\section{Literature Cited}

Allan, J. D., D. L. Erickson and J. Fay. 1997. The Influence of Catchment Land Use on Stream Integrity Across Multiple Spatial Scales. Freshwater Biology 37:149-162.

Barbour, M., J. Gerritsen, B.D. Snyder, and J.B. Stribling. 1999. Rapid Bioassessment Protocols for Use in Streams and Wadable Rivers: Periphyton, Benthic Macroinvertebrates and Fish, Second Edition. EPA 841-B-99-002. United States Environmental Protection Agency; Office of Water: Washington, D.C.

BLM 2008. Standard Methods for Laboratory Sample Sorting Procedures of Macroinvertebrate Samples. http://usu.edu/buglab/SampleProcessing/labProcedures.cfm Bureau of Land Management/USU National Aquatic Monitoring Center, Logan, Utah.

BLM 2008b. Standard Methods for Field Surveys of Macroinvertebrate Samples. http://www.usu.edu/buglab/Monitoring/fieldForms.cfm Bureau of Land Management/USU National Aquatic Monitoring Center, Logan, Utah.

Bramblett, R. G., T. R. Johnson, A. V. Zale, A. V., and D. Heggem. 2005. Development and Evaluation of a Fish Assemblage Index of Biotic Integrity for Northwestern Great Plains. Transactions of the American Fisheries Society 134:624-640, 2005.

Bramblett, R. G., and K. D. Fausch. 1991. Variable Fish Communities and the Index of Biotic Integrity in a Western Great Plains River. Transactions of the American Fisheries Society 120:752-769.

Dodds, W. K., K. Gido, M. R. Whiles, K. M. Fritz, and W. J. Matthews. 2004. Life on the Edge: The Ecology of Great Plains Prairie Streams. BioScience 54: 205-216.

DOI Bureau of Land Management 2002. Environmental Assessment. http://dnrc.mt.gov/Trust/MMB/OtterCreek/2General/TransferDocuments/BLMTransferEA.pdf

Feldman, D. 2006. Interpretation of New Macroinvertebrate Models by WQPB. Draft Report. Montana Department of Environmental Quality, Planning Prevention and Assistance Division, Water Quality Planning Bureau, Water Quality Standards Section.1520 E. $6^{\text {th }}$ Avenue, Helena, MT 59620. 14 pp.

George, M.R., R.E. Larsen, N.K. McDougald, K.W. Tate, J.D. Gerlach, Jr., and K.O. Fulgham. 2002. Influence of Grazing on Channel Morphology of Intermittent Streams. J. Range Management. 55:551-557.

Hawkins, C. P. and R. H. Norris. 2000. Performance of different landscape classifications for aquatic bioassessments: introduction to the series. Journal of the North American Benthological Society.19:3 (367-369). 
Holton, G. D., and H. E. Johnson. 2003. A Field Guide to Montana Fishes, 3rd edition. Montana Fish, Wildlife, and Parks, Helena.

Jessup, B., J. Stribling; and C. Hawkins. 2005. Biological Indicators of Stream Condition in Montana Using Macroinvertebrates. Tetra Tech, Inc. November 2005 (draft).

Jessup, B. 2006. Ecological Data Application System (EDAS) Version MT 3.3.2k A User's Guide. Tetra Tech, Inc.

Karr, J. R. 1981. Assessment of Biotic Integrity Using Fish Communities. Fisheries 6(6):21-27.

Lazorchak, J.M., Klemm, D.J., and D.V. Peck (editors). 1998. Environmental Monitoring and Assessment Program - Surface Waters: Field Operations and Methods for Measuring the Ecological Condition of Wadeable Streams. EPA/620/R-94/004F. U.S. Environmental Protection Agency, Washington, D.C.

Montana Department of Environmental Quality (DEQ). 2006. Sample Collection, Sorting, and Taxonomic Identification of Benthic Macroinvertebrates. Water Quality Planning Bureau. Standard Operation Procedure (WQPBWQM-009).

Montana Department of Environmental Quality (DEQ). 2006. ADMINISTRATIVE RULES OF MONTANA 17.30.670. Chapter 30 Surface Water Quality Standards and Procedures. www.deq.mt.gov/dir/Legal/Chapters/Ch30-06.pdf

Peterson, D.A., Clark, M.L., Foster, Katharine, Wright, P.R., and Boughton, G.K., 2010, Assessment of Ecological Conditions and Potential Effects of Water Produced From Coalbed Natural Gas Development on Biological Communities in Streams of the Powder River Structural Basin, Wyoming and Montana, 2005-08: USGS Scientific Investigations Report 2010-5124, 84 p. http://pubs.usgs.gov/sir/2010/5124/pdf/SIR10-5124.pdf

Pritchard, D., F. Barret, H. Berg, W. Hagenbuck, R. Krapf, R. Leinard, S. Leonard, M. Manning, C. Noble, Tippy, D. 1993. Riparian Area Management: A User Guide to Assessing Proper Functioning Condition. Technical Reference 1737-9. USDI Bureau of Land Management Service Center. Denver, Colorado. USA. 109 pp.

Stagliano, David, M. 2011. Baseline Assessments for Fish, Macroinvertebrates, and Herpetofauna in the Headwaters of Otter and Hanging Woman Creeks within the Tongue Powder CBNG Area. Report to the Bureau of Land Management. Montana Natural Heritage Program, Helena, Montana. 17 pp. http://mtnhp.org/reports/CBNG TonguePowder.pdf

Stagliano, David, M. 2005. Aquatic Community Classification and Ecosystem Diversity in Montana's Missouri River Watershed. Report to the Bureau of Land Management. Montana Natural Heritage Program, Helena, Montana. 65 pp. plus appendices. http://www.mtnhp.org/reports.asp\#Ecology 
Appendix A. Raw data and IBI metric calculation from fish data collected from Otter Creek Coal Tract Sites

\begin{tabular}{|c|c|c|c|c|c|c|c|c|c|c|}
\hline & \multicolumn{9}{|c|}{ Spring 2011} & \\
\hline & Otter23 & & Otter22 & & Otter16 & & OtterJT & & Otter1A & \\
\hline Black Bullhead & 0.0 & & 0.0 & & 0.0 & & 12.5 & & 0.0 & \\
\hline Brassy Minnow & 25.0 & & 81.0 & & 100.0 & & 142.5 & & 0.0 & \\
\hline Common Carp & 0.0 & & 0.0 & & 4.0 & & 20.0 & & 0.0 & \\
\hline Fathead Minnow & 0.0 & & 0.0 & & 16.0 & & 2007.5 & & 10.0 & \\
\hline Lake Chub & 12.0 & & 153.0 & & 40.0 & & 5.0 & & 20.0 & \\
\hline Green Sunfish & 0.0 & & 0.0 & & 0.0 & & 2.5 & & 0.0 & \\
\hline Pumpkinseed Sunfish & 0.0 & & 0.0 & & 0.0 & & 0.0 & & 0.0 & \\
\hline Sand Shiner & 0.0 & & 0.0 & & 0.0 & & 37.5 & & 0.0 & \\
\hline White Sucker & 0.0 & & 6.0 & & 20.0 & & 27.5 & & 0.0 & \\
\hline Total \# species & 2.0 & & 3.0 & & 5.0 & & 8.0 & & 2.0 & \\
\hline Native Species & 2.0 & & 3.0 & & 4.0 & & 5.0 & & 2.0 & \\
\hline Native Families & 1.0 & & 2.0 & & 2.0 & & 2.0 & & 1.0 & \\
\hline Total Individuals & 37.0 & & 240.0 & & 180.0 & & 2255.0 & & 30.0 & \\
\hline $\begin{array}{l}\text { \# Minnow Species Thrive } \\
\text { Proportion of tolerant } \\
\text { individuals }\end{array}$ & $\begin{array}{l}2.0 \\
0.00\end{array}$ & & $\begin{array}{l}2.0 \\
2.50\end{array}$ & & $\begin{array}{r}3.0 \\
22.22\end{array}$ & & $\begin{array}{c}4.0 \\
91.80\end{array}$ & & $\begin{array}{r}2.0 \\
33.33 \\
\end{array}$ & \\
\hline \# Sucker + Catfish Species & 0.0 & & 1.0 & & 1.0 & & 2.0 & & 0.0 & \\
\hline$\%$ Insectivorous Minnows & 32.4 & & 63.8 & & 22.2 & & 1.9 & & 66.7 & \\
\hline \# Benthic Invertivore Species & 0.0 & & 0.0 & & 0.0 & & 1.0 & & 0.0 & \\
\hline$\%$ Litholphilic Spawners & 0.0 & & 2.5 & & 11.1 & & 2.9 & & 0.0 & \\
\hline$\%$ Parental Care & 0.00 & & 0.00 & & 8.89 & & 89.58 & & 33.33 & \\
\hline$\%$ Native to Montana & 100.0 & & 100.0 & & 97.8 & & 98.4 & & 100.0 & \\
\hline \multirow[t]{2}{*}{ \# Long Lived Species } & 2.0 & & 1.0 & & 2.0 & & 4.0 & & 1.0 & \\
\hline & Otter23 & & Otter22 & & Otter16 & & OtterJT & & Otter1A & \\
\hline Metrics & Adjust Value & Score & Adjust Value & Score & $\begin{array}{l}\text { Adjust } \\
\text { Value }\end{array}$ & Score & $\begin{array}{l}\text { Adjust } \\
\text { Value } \\
\end{array}$ & Score & \begin{tabular}{|l|} 
Adjust \\
Value
\end{tabular} & Score \\
\hline $\begin{array}{l}\text { Number of Native Fish Species } \\
\text { to Montana }\end{array}$ & 13.6 & 75.8 & 9.3 & 51.8 & 10.1 & 56.0 & 10.8 & 59.9 & 13.3 & 73.7 \\
\hline $\begin{array}{l}\text { Number of Native Fish Families } \\
\text { to Montana }\end{array}$ & 3.1 & 58.0 & 3.2 & 58.7 & 3.1 & 57.8 & 3.1 & 56.8 & 3.1 & 56.7 \\
\hline $\begin{array}{l}\text { Proportion of tolerant } \\
\text { individuals }\end{array}$ & 0.0 & 100.0 & 2.5 & 97.4 & 22.2 & 76.5 & 91.8 & 2.9 & 33.3 & 64.7 \\
\hline $\begin{array}{l}\text { Number of Sucker and Catfish } \\
\text { Species }\end{array}$ & 7.1 & 77.1 & 4.9 & 53.3 & 4.8 & 51.7 & 5.6 & 60.7 & 6.9 & 74.7 \\
\hline $\begin{array}{l}\text { Proportion out of the Total } \\
\text { Number of Fish That Were } \\
\text { Insect eating Minnows }\end{array}$ & 32.4 & 44.5 & 63.8 & 87.6 & 22.2 & 30.5 & 1.9 & 2.6 & 66.7 & 91.6 \\
\hline $\begin{array}{l}\text { Total Number of Species That } \\
\text { Prefer to Eat Insects That Live } \\
\text { on the Stream Bottom }\end{array}$ & 5.5 & 93.1 & 3.0 & 51.3 & 4.9 & 83.3 & 4.8 & 81.0 & 5.3 & 90.2 \\
\hline $\begin{array}{l}\text { Proportion of the Total } \\
\text { Number of Fish That Require } \\
\text { Rocks to Lay Eggs }\end{array}$ & 0.0 & 0.0 & 2.5 & 3.0 & 11.1 & 13.4 & 2.9 & 3.5 & 0.0 & 0.0 \\
\hline $\begin{array}{l}\text { Proportion of the Total } \\
\text { Number of Individuals That Do } \\
\text { Not Require Rocks, But Have } \\
\text { Parental Care of Eggs }\end{array}$ & 0.0 & 100.0 & 0.0 & 100.0 & 8.9 & 89.9 & 89.6 & -1.9 & 33.3 & 62.1 \\
\hline $\begin{array}{l}\text { Proportion of the Total } \\
\text { Number of Fish Sampled That } \\
\text { Were Native to Montana }\end{array}$ & 100.0 & 100.0 & 100.0 & 100.0 & 97.8 & 97.8 & 98.4 & 98.5 & 100.0 & 100.0 \\
\hline \multirow[t]{2}{*}{$\begin{array}{l}\text { Number of Long-Lived Native } \\
\text { Species }\end{array}$} & 10.5 & 107.4 & 5.7 & 58.1 & 6.5 & 66.5 & 8.3 & 84.9 & 9.2 & 94.5 \\
\hline & & 756.0 & & 661.2 & & 623.5 & & 448.9 & & 708.4 \\
\hline IBI Score & & 75.60 & & 66.12 & & 62.35 & & 44.89 & & 70.84 \\
\hline
\end{tabular}


Appendix A. Raw data and IBI metric calculation from fish data collected from Otter Creek Coal Tract Sites

Summer 2011

\begin{tabular}{|c|c|c|c|c|c|c|c|c|c|c|c|c|}
\hline & Otter23 & & Otter22 & & Otter16 & & Otter2 & & OtterJT & & Otter1A & \\
\hline Black Bullhead & 0.0 & & 5.0 & & 0.0 & & 7.0 & & 2.5 & & 0.0 & \\
\hline Brassy Minnow & 0.0 & & 2400.0 & & 549.0 & & 154.0 & & 30.0 & & 0.0 & \\
\hline Common Carp & 0.0 & & 0.0 & & 432.0 & & 14.0 & & 212.5 & & 0.0 & \\
\hline Fathead Minnow & 0.0 & & 0.0 & & 3.0 & & 56.0 & & 2995.0 & & 10.0 & \\
\hline Lake Chub & 0.0 & & 2785.0 & & 84.0 & & 105.0 & & 7.5 & & 20.0 & \\
\hline Green Sunfish & 0.0 & & 0.0 & & 0.0 & & 0.0 & & 2.5 & & 0.0 & \\
\hline Sand Shiner & 0.0 & & 0.0 & & 0.0 & & 22.0 & & 25.0 & & 0.0 & \\
\hline White Sucker & 0.0 & & 140.0 & & 0.0 & & 7.0 & & 107.5 & & 0.0 & \\
\hline Total \# species & 0.0 & & 4.0 & & 5.0 & & 8.0 & & 8.0 & & 2.0 & \\
\hline Native Species & 0.0 & & 3.0 & & 3.0 & & 5.0 & & 5.0 & & 2.0 & \\
\hline Native Families & 0.0 & & 2.0 & & 1.0 & & 2.0 & & 2.0 & & 1.0 & \\
\hline Total Individuals & 0.0 & & 5330.0 & & 1071.0 & & 372.0 & & 3382.5 & & 30.0 & \\
\hline $\begin{array}{l}\text { \# Minnow Species Thrive } \\
\text { Proportion of tolerant } \\
\text { individuals }\end{array}$ & $\begin{array}{l}0.0 \\
0.00\end{array}$ & & $\begin{array}{l}2.0 \\
2.72\end{array}$ & & $\begin{array}{r}3.0 \\
40.62 \\
\end{array}$ & & $\begin{array}{r}4.0 \\
22.58\end{array}$ & & $\begin{array}{r}4.0 \\
98.15 \\
\end{array}$ & & $\begin{array}{r}2.0 \\
33.33 \\
\end{array}$ & \\
\hline \# Sucker + Catfish Species & 0.0 & & 2.0 & & 0.0 & & 2.0 & & 2.0 & & 0.0 & \\
\hline$\%$ Insectivorous Minnows & 0.0 & & 52.3 & & 7.8 & & 34.1 & & 1.0 & & 66.7 & \\
\hline \# Benthic Invertivore Species & 0.0 & & 1.0 & & 0.0 & & 1.0 & & 1.0 & & 0.0 & \\
\hline \% Litholphilic Spawners & 0.0 & & 2.6 & & 0.0 & & 7.8 & & 3.9 & & 0.0 & \\
\hline$\%$ Parental Care & 0.00 & & 0.09 & & 0.28 & & 16.94 & & 88.62 & & 33.33 & \\
\hline$\%$ Native to Montana & 0.0 & & 99.9 & & 59.4 & & 92.5 & & 93.6 & & 100.0 & \\
\hline \multirow[t]{2}{*}{ \# Long Lived Species } & 0.0 & & 1.0 & & 2.0 & & 1.0 & & 4.0 & & 1.0 & \\
\hline & Otter23 & & Otter22 & & Otter16 & & Otter2 & & OtterJT & & Otter1A & \\
\hline Metrics & $\begin{array}{l}\text { Adjust } \\
\text { Value } \\
\end{array}$ & & $\begin{array}{l}\text { Adjust } \\
\text { Value } \\
\end{array}$ & & $\begin{array}{l}\text { Adjust } \\
\text { Value } \\
\end{array}$ & & $\begin{array}{l}\text { Adjust } \\
\text { Value } \\
\end{array}$ & & $\begin{array}{l}\text { Adjust } \\
\text { Value } \\
\end{array}$ & & $\begin{array}{l}\text { Adjust } \\
\text { Value } \\
\end{array}$ & Score \\
\hline $\begin{array}{l}\text { Number of Native Fish Species } \\
\text { to Montana }\end{array}$ & 11.6 & 64.7 & 9.3 & 51.8 & 9.1 & 50.4 & 11.1 & 61.5 & 10.8 & 59.9 & 13.3 & 73.7 \\
\hline $\begin{array}{l}\text { Number of Native Fish Families } \\
\text { to Montana }\end{array}$ & 2.1 & 39.5 & 3.2 & 58.7 & 2.1 & 39.4 & 3.1 & 57.8 & 3.1 & 56.8 & 3.1 & 56.7 \\
\hline $\begin{array}{l}\text { Proportion of tolerant } \\
\text { individuals }\end{array}$ & 0.0 & 100.0 & 2.7 & 97.1 & 40.6 & 57.0 & 22.6 & 76.1 & 98.2 & -3.9 & 33.3 & 64.7 \\
\hline $\begin{array}{l}\text { Number of Sucker and Catfish } \\
\text { Species }\end{array}$ & 7.1 & 77.1 & 5.9 & 64.2 & 3.8 & 40.8 & 5.8 & 62.6 & 5.6 & 60.7 & 6.9 & 74.7 \\
\hline $\begin{array}{l}\text { Proportion out of the Total } \\
\text { Number of Fish That Were } \\
\text { Insect eating Minnows }\end{array}$ & 0.0 & 0.0 & 52.3 & 71.8 & 7.8 & 10.8 & 34.1 & 46.9 & 1.0 & 1.3 & 66.7 & 91.6 \\
\hline $\begin{array}{l}\text { Total Number of Species That } \\
\text { Prefer to Eat Insects That Live } \\
\text { on the Stream Bottom }\end{array}$ & 5.5 & 93.1 & 4.0 & 68.3 & 4.9 & 83.3 & 4.9 & 83.3 & 4.8 & 81.0 & 5.3 & 90.2 \\
\hline $\begin{array}{l}\text { Proportion of the Total } \\
\text { Number of Fish That Require } \\
\text { Rocks to Lay Eggs }\end{array}$ & 0.0 & 0.0 & 2.6 & 3.2 & 0.0 & 0.0 & 7.8 & 9.4 & 3.9 & 4.7 & 0.0 & 0.0 \\
\hline $\begin{array}{l}\text { Proportion of the Total } \\
\text { Number of Individuals That Do } \\
\text { Not Require Rocks, But Have } \\
\text { Parental Care of Eggs }\end{array}$ & 0.0 & 100.0 & 0.1 & 99.9 & 0.3 & 99.7 & 16.9 & 80.7 & 88.6 & -0.8 & 33.3 & 62.1 \\
\hline $\begin{array}{l}\text { Proportion of the Total } \\
\text { Number of Fish Sampled That } \\
\text { Were Native to Montana }\end{array}$ & 0.0 & 0.0 & 99.9 & 99.9 & 59.4 & 59.4 & 92.5 & 92.5 & 93.6 & 93.6 & 100.0 & 100.0 \\
\hline \multirow[t]{2}{*}{$\begin{array}{l}\text { Number of Long-Lived Native } \\
\text { Species }\end{array}$} & 8.5 & 86.9 & 5.7 & 58.1 & 6.5 & 66.5 & 5.5 & 56.3 & 8.3 & 84.9 & 9.2 & 94.5 \\
\hline & & 561.4 & & 673.0 & & 507.4 & & 627.2 & & 438.3 & & 708.4 \\
\hline IBI Score & & 56.14 & & 67.30 & & 50.74 & & 62.72 & & 43.83 & & 70.84 \\
\hline
\end{tabular}


Appendix A. Raw data and IBI metric calculation from fish data collected from Otter Creek Coal Tract Sites

Fall 2011

\begin{tabular}{|c|c|c|c|c|c|c|c|c|c|c|c|c|}
\hline & Otter23 & & Otter22 & & Otter16 & & Otter2 & & OtterJT & & Otter1A & \\
\hline Black Bullhead & 0.0 & & 3.0 & & 186.0 & & 7.0 & & 5.0 & & 0.0 & \\
\hline Brassy Minnow & 0.0 & & 588.0 & & 51.0 & & 364.0 & & 65.0 & & 0.0 & \\
\hline Common Carp & 0.0 & & 0.0 & & 1314.0 & & 49.0 & & 137.5 & & 0.0 & \\
\hline Fathead Minnow & 0.0 & & 3.0 & & 12.0 & & 35.0 & & 17810.0 & & 10.0 & \\
\hline Lake Chub & 0.0 & & 1059.0 & & 9.0 & & 84.0 & & 102.5 & & 0.0 & \\
\hline Green Sunfish & 0.0 & & 3.0 & & 6.0 & & 0.0 & & 2.5 & & 0.0 & \\
\hline Pumpkinseed Sunfish & 0.0 & & 3.0 & & 30.0 & & 0.0 & & 10.0 & & 0.0 & \\
\hline Sand Shiner & 0.0 & & 0.0 & & 0.0 & & 0.0 & & 2755.0 & & 0.0 & \\
\hline White Sucker & 0.0 & & 15.0 & & 45.0 & & 7.0 & & 10.0 & & 0.0 & \\
\hline Total \# species & 0.0 & & 7.0 & & 8.0 & & 6.0 & & 9.0 & & 1.0 & \\
\hline Native Species & 0.0 & & 4.0 & & 4.0 & & 4.0 & & 5.0 & & 1.0 & \\
\hline Native Families & 0.0 & & 2.0 & & 2.0 & & 2.0 & & 2.0 & & 1.0 & \\
\hline Total Individuals & 0.0 & & 1674.0 & & 1653.0 & & 546.0 & & 20897.5 & & 10.0 & \\
\hline $\begin{array}{l}\text { \# Minnow Species Thrive } \\
\text { Proportion of tolerant } \\
\text { individuals }\end{array}$ & 0.0 & & $\begin{array}{l}3.0 \\
1.43\end{array}$ & & $\begin{array}{r}3.0 \\
94.56\end{array}$ & & $\begin{array}{c}3.0 \\
17.95\end{array}$ & & $\begin{array}{c}4.0 \\
85.97\end{array}$ & & 1.0 & \\
\hline \# Sucker + Catfish Species & 0.0 & & 2.0 & & 2.0 & & 2.0 & & 2.0 & & 0.0 & \\
\hline$\%$ Insectivorous Minnows & 0.0 & & 63.3 & & 0.5 & & 15.4 & & 13.7 & & 0.0 & \\
\hline \# Benthic Invertivore Species & 0.0 & & 1.0 & & 1.0 & & 1.0 & & 1.0 & & 0.0 & \\
\hline \% Litholphilic Spawners & 0.0 & & 0.9 & & 2.7 & & 1.3 & & 13.2 & & 0.0 & \\
\hline$\%$ Parental Care & 0.00 & & 0.36 & & 11.98 & & 7.69 & & 85.25 & & 100.00 & \\
\hline$\%$ Native to Montana & 0.0 & & 99.5 & & 7.1 & & 89.7 & & 99.3 & & 100.0 & \\
\hline \multirow[t]{2}{*}{ \# Long Lived Species } & 0.0 & & 4.0 & & 4.0 & & 4.0 & & 4.0 & & 1.0 & \\
\hline & Otter23 & & Otter22 & & Otter16 & & Otter2 & & OtterJT & & Otter1A & \\
\hline Metrics & $\begin{array}{l}\text { Adjust } \\
\text { Value } \\
\end{array}$ & & $\begin{array}{l}\text { Adjust } \\
\text { Value } \\
\end{array}$ & & \begin{tabular}{|l|}
$\begin{array}{l}\text { Adjust } \\
\text { Value }\end{array}$ \\
\end{tabular} & & \begin{tabular}{|l|} 
Adjust \\
Value \\
\end{tabular} & & $\begin{array}{l}\text { Adjust } \\
\text { Value } \\
\end{array}$ & & $\begin{array}{l}\text { Adjust } \\
\text { Value } \\
\end{array}$ & Score \\
\hline $\begin{array}{l}\text { Number of Native Fish Species } \\
\text { to Montana }\end{array}$ & 11.6 & 64.7 & 10.3 & 57.4 & 10.1 & 56.0 & 10.1 & 56.0 & 10.8 & 59.9 & 12.3 & 68.2 \\
\hline $\begin{array}{l}\text { Number of Native Fish Families } \\
\text { to Montana }\end{array}$ & 2.1 & 39.5 & 3.2 & 58.7 & 3.1 & 57.8 & 3.1 & 57.8 & 3.1 & 56.8 & 3.1 & 56.7 \\
\hline $\begin{array}{l}\text { Proportion of tolerant } \\
\text { individuals }\end{array}$ & 0.0 & 100.0 & 1.4 & 98.5 & 94.6 & -0.1 & 17.9 & 81.0 & 86.0 & 9.0 & 100.0 & -5.8 \\
\hline $\begin{array}{l}\text { Number of Sucker and Catfish } \\
\text { Species }\end{array}$ & 7.1 & 77.1 & 5.9 & 64.2 & 5.8 & 62.6 & 5.8 & 62.6 & 5.6 & 60.7 & 6.9 & 74.7 \\
\hline $\begin{array}{l}\text { Proportion out of the Total } \\
\text { Number of Fish That Were } \\
\text { Insect eating Minnows }\end{array}$ & 0.0 & 0.0 & 63.3 & 86.9 & 0.5 & 0.7 & 15.4 & 21.1 & 13.7 & 18.8 & 0.0 & 0.0 \\
\hline $\begin{array}{l}\text { Total Number of Species That } \\
\text { Prefer to Eat Insects That Live } \\
\text { on the Stream Bottom }\end{array}$ & 5.5 & 93.1 & 4.0 & 68.3 & 4.9 & 83.3 & 4.9 & 83.3 & 4.8 & 81.0 & 5.3 & 90.2 \\
\hline $\begin{array}{l}\text { Proportion of the Total } \\
\text { Number of Fish That Require } \\
\text { Rocks to Lay Eggs }\end{array}$ & 0.0 & 0.0 & 0.9 & 1.1 & 2.7 & 3.3 & 1.3 & 1.5 & 13.2 & 16.0 & 0.0 & 0.0 \\
\hline $\begin{array}{l}\text { Proportion of the Total } \\
\text { Number of Individuals That Do } \\
\text { Not Require Rocks, But Have } \\
\text { Parental Care of Eggs }\end{array}$ & 0.0 & 100.0 & 0.4 & 99.6 & 12.0 & 86.4 & 7.7 & 91.3 & 85.2 & 3.0 & 100.0 & -13.7 \\
\hline $\begin{array}{l}\text { Proportion of the Total } \\
\text { Number of Fish Sampled That } \\
\text { Were Native to Montana }\end{array}$ & 0.0 & 0.0 & 99.5 & 99.5 & 7.1 & 7.1 & 89.7 & 89.8 & 99.3 & 99.3 & 100.0 & 100.0 \\
\hline \multirow[t]{2}{*}{$\begin{array}{l}\text { Number of Long-Lived Native } \\
\text { Species }\end{array}$} & 8.5 & 86.9 & 5.7 & 58.1 & 8.5 & 87.0 & 8.5 & 87.0 & 8.3 & 84.9 & 9.2 & 94.5 \\
\hline & & 561.4 & & 692.2 & & 444.2 & & 631.4 & & 489.4 & & 464.9 \\
\hline IBI Score & & 56.14 & & 69.22 & & 44.42 & & 63.14 & & 48.94 & & 46.49 \\
\hline
\end{tabular}


Appendix C . Habitat and Water Quality Parameters measured for the Otter Creek sites visited. NA = not visited or sampled during this visit, dry.

\begin{tabular}{|c|c|c|c|c|c|c|c|c|c|c|c|c|c|c|c|c|c|c|c|c|c|}
\hline & \multicolumn{3}{|c|}{ OTTER_23 } & \multicolumn{3}{|c|}{ OTTER_22 } & \multicolumn{3}{|c|}{ OTTER_16 } & \multicolumn{3}{|c|}{ OTTER_3m } & \multicolumn{3}{|c|}{ OTTER_2 } & \multicolumn{3}{|c|}{ OTTER_JT } & \multicolumn{3}{|c|}{ OTTER_1A } \\
\hline & May & Jul & Oct & May & Jul & Oct & May & Jul & Oct & May & Jul & Oct & May & Jul & Oct & May & Jul & Oct & May & Jul & Oct \\
\hline Water Temp @ & 17.4 & 30.8 & 3.8 & 12.3 & 28.5 & 7.5 & 12.9 & 24.6 & 8.8 & 14.5 & na & na & na & 26.6 & 9.2 & 13.1 & 26.8 & 10.7 & 18.6 & 27.8 & 9.1 \\
\hline Conductivity $(\mu \mathrm{s} / \mathrm{cm})$ & 1880 & $>4,000$ & $>4,000$ & 3660 & 3790 & 3590 & $>4,000$ & 3920 & 3790 & 170 & na & na & na & 3890 & 3700 & 3860 & 3608 & 3540 & 1950 & $>4,000$ & 3209 \\
\hline $\mathrm{pH}$ & 8.2 & 8.4 & 8.4 & 8.2 & 8.2 & 8.1 & 7.6 & 7.8 & 8 & 7.8 & na & na & na & 8.2 & 8.1 & 8.1 & 8.1 & 8.1 & 8.2 & 8.2 & 8.2 \\
\hline PFC & FAR & FAR & FAR & PFC & PFC & PFC & PFC & PFC & FAR & FAR & FAR & FAR & na & FAR & FAR & PFC & PFC & PFC & FAR & FAR & FAR \\
\hline BLM HBI & 16 & 17 & 17 & 22 & 22 & 22 & 19 & 19 & 18 & 17 & 18 & 18 & na & 17 & 17 & 19 & 19 & 19 & 11 & 12 & 13 \\
\hline Avg wetted width (m) & 6.2 & 0.6 & 0.6 & 8.7 & 8.2 & 8.6 & 11.9 & 12.1 & 11.2 & 1.8 & na & na & na & 4.2 & 2.8 & 5.0 & 4.8 & 4.6 & 2.4 & 2.1 & 2.0 \\
\hline Avg Left CHD (cm) & 25 & 2 & 2 & 71 & 67 & 71 & 103 & 104 & 93 & 2 & na & na & na & 30 & 22 & 53 & 43 & 36 & 22 & 28 & 31 \\
\hline Avg Center CHD (cm) & 32 & 3 & 3 & 76 & 97 & 76 & 136 & 128 & 106 & 2 & na & na & na & 42 & 30 & 54 & 44 & 40 & 30 & 33 & 42 \\
\hline Avg Right CHD (cm) & 27 & 2 & 2 & 70 & 66 & 70 & 95 & 92 & 86 & 2 & na & na & na & 25 & 20 & 55 & 41 & 36 & 18 & 25 & 29 \\
\hline$\%$ Fines in Reach & 98 & 100 & 100 & 92 & 84 & 92 & 97 & 97 & 89 & 100 & 100 & 100 & na & 50 & 60 & 70 & 67 & 63 & 100 & 100 & 98 \\
\hline$\%$ Gravel Reach & 2 & 0 & 0 & 4 & 8 & 4 & 3 & 3 & 8 & 0 & 0 & 0 & na & 35 & 30 & 20 & 26 & 34 & 1 & 1 & 3 \\
\hline$\%$ Cobble Reach & 0 & 0 & 0 & 5 & 9 & 5 & 1 & 1 & 5 & 0 & 0 & 0 & na & 15 & 10 & 11 & 8 & 3 & 0 & 0 & 0 \\
\hline Livestock Use (CPI) & 30 & 11 & 9 & 55 & 36 & 13 & 18 & 7 & 46 & 35 & 44 & 24 & na & 12 & 5 & 18 & 22 & 19 & 55 & 36 & 28 \\
\hline Avg. Riparian Shade & 0 & 5 & 0 & 0 & 10 & 0 & 5 & 10 & 10 & 10 & 40 & 20 & na & 10 & 10 & 10 & 20 & 10 & 10 & 30 & 20 \\
\hline
\end{tabular}

